\title{
Base-Displaced Intercalated Structure of the Food Mutagen 2- Amino-3-methylimidazo[4,5-f]quinoline in the Recognition Sequence of the Narl Restriction Enzyme, a Hotspot for -2 bp Deletions
}

\author{
Feng Wang, Nicholas E. DeMuro, C. Eric Elmquist, James S. Stover, Carmelo J. Rizzo, and \\ Michael P. Stone \\ Department of Chemistry, Center in Molecular Toxicology, Vanderbilt-Ingram Cancer Center, \\ Vanderbilt University, Nashville, Tennessee 37235
}

\begin{abstract}
The solution structure of the oligodeoxynucleotide $5^{\prime}-\mathrm{d}\left(\right.$ CTCGGCXCCATC) $-3^{\prime} \cdot 5^{\prime}-\mathrm{d}$ (GATGGCGCCGAG)-3' containing the heterocyclic amine 8-[(3-methyl-3H-imidazo[4,5-f] quinolin-2-yl)amino]-2'-deoxyguanosine adduct (IQ) at the third guanine in the NarI restriction sequence, a hot spot for $-2 \mathrm{bp}$ frameshifts, is reported. Molecular dynamics calculations restrained by distances derived from $24{ }^{1} \mathrm{H}$ NOEs between IQ and DNA, and torsion angles derived from ${ }^{3} \mathbf{J}$ couplings, yielded ensembles of structures in which the adducted guanine was displaced into the major groove with its glycosyl torsion angle in the syn conformation. One proton of its exocyclic amine was approximately $2.8 \AA$ from an oxygen of the 5 ' phosphodiester linkage, suggesting formation of a hydrogen bond. The carcinogen-guanine linkage was defined by torsion angles $\alpha^{\prime}$ [N9-C8-N(IQ)-C2(IQ)] of $159 \pm 7^{\circ}$ and $\beta^{\prime}$ [C8-N(IQ)-C2(IQ)-N3(IQ)] of $-23 \pm 8^{\circ}$. The complementary cytosine was also displaced into the major groove. This allowed IQ to intercalate between the flanking C.G base pairs. The disruption of Watson-Crick hydrogen bonding was corroborated by chemical-shift perturbations for base aromatic protons in the complementary strand opposite to the modified guanine. Chemical-shift perturbations were also observed for ${ }^{31} \mathrm{P}$ resonances corresponding to phosphodiester linkages flanking the adduct. The results confirmed that IQ adopted a base-displaced intercalated conformation in this sequence context but did not corroborate the formation of a hydrogen bond between the IQ quinoline nitrogen and the complementary $\mathrm{dC}$.
\end{abstract}

\section{Introduction}

The browning of protein-rich foods imparts flavor during cooking. It leads to the formation of heterocyclic amines (HCA) such as 2-amino-3-methylimidazo[4,5-f] quinoline (IQ). ${ }^{1-4}$ Various HCAs, including IQ, have been identified in grilled foods at ppb levels. 5,6 Daily human intakes of HCAs, estimated to be $\sim 60 \mathrm{ng} / \mathrm{day},{ }^{7}$ are modest; however, exposure to these

\footnotetext{
(C) 2006 American Chemical Society

E-mail: E-mail: michael.p.stone@ vanderbilt.edu; E-mail: carmelo.rizzo@vanderbilt.edu.

Supporting Information Available: Tables S1 and S2, nonexchangeable proton chemical shifts of the Nar1IQ3 and unmodified duplexes; S3, exchangeable proton chemical shifts for the Nar1IQ3 and unmodified duplexes; S4, comparison of experimental intermolecular distance restraints with those observed for intensity-refined structures of the Nar1IQ3 duplex; and S5, pseudorotation and glycosyl torsion angles for the Nar 1IQ3 and unmodified duplexes. Figures S1, contour plots of the anomeric to aromatic region of the ${ }^{1} \mathrm{H}$ NOESY spectrum for the unmodified duplex; S2, contour plot of the imino protons of the unmodified duplex; S3, stereoview of 10 superimposed structures emergent from $\mathrm{rMD}$ calculations on the unmodified duplex; and S4, $\mathrm{R}_{1}{ }^{x}$ values for refined structures of the unmodified duplex calculated using the program CORMA (v. 5.2). ${ }^{72}$ This material is available free of charge via the Internet at http://pubs.acs.org.
} 
compounds, which have been isolated from human urine, ${ }^{8}$ is of concern with regard to human health.

Exposure to IQ is associated with carcinogenesis. Tumors in organs of rodents and in the livers of monkeys are induced by IQ. ${ }^{9-11,16}$ In mice, exposures lead to liver, forestomach, and lung tumors. ${ }^{12}$ In rats, exposures lead to cancers in the liver, intestine, zymbal gland, clitoral gland, skin, ${ }^{13}$ mammary glands, liver, and ear ducts. ${ }^{14}$ TD50 values for in rats are $0.7 \mathrm{mg} / \mathrm{kg} / \mathrm{day}$, and in mice are $14.7 \mathrm{mg} / \mathrm{kg} / \mathrm{day} .{ }^{15}$ Human exposure to HCAs is associated with pancreatic, 17 colon, ${ }^{18}$ prostate, ${ }^{19}$ and breast cancer. ${ }^{20,21}$

In bacterial reversion assays, ${ }^{22-25}$ HCAs are active in point and frameshift tester strains. ${ }^{26}$ IQ is one of the strongest chemical mutagens. ${ }^{27}$ It is less prevalent than 2-amino-1-methyl-6phenylimidazo[4,5-b]pyridine ( $\mathrm{PhIP})^{28}$ but is 200 -fold more mutagenic than the latter in Salmonella reversion assays. ${ }^{3} \mathrm{IQ}$ is an order of magnitude more mutagenic than is aflatoxin $B_{1}$. In bacteria, mutations occur primarily at $\mathrm{G}: \mathrm{C}$ base pairs. ${ }^{29,30}$ It exhibits frameshift mutations in CG repeats. Similar levels of mutations are seen in mammalian $h p r t^{31}$ and ef- $2^{32}$ gene assays. In mammalian cells, point mutations are observed. ${ }^{33-36}$ Sister chromatid exchanges are observed in rodent cells. ${ }^{37-39}$

IQ is activated primarily by the enzyme CYP P450 $1 \mathrm{~A} 2$ to an $N$-hydroxyl oxidation product. 40-43 Extra-hepatic CYP P450s oxidize HCAs with lower efficiencies. ${ }^{44}$ The $N$-hydroxyl oxidation product is acetylated by cellular $N$-acetyl transferases, particularly NAT2. ${ }^{45-47}$ The resulting nitrenium ion is the ultimate reactive electrophile. ${ }^{36,44}$ The NAT2 fast acetylator polymorphism is associated with an increased risk of colorectal cancer in humans. ${ }^{48,49}$

The C8-dG adducts of HCAs are observed both in rodents and primates, as measured by ${ }^{32} \mathrm{P}$ postlabeling. ${ }^{35}$ The major adduct formed by IQ occurs by substitution at C8-dG (Chart 1); a minor $N^{2}$-dG adduct is also formed. ${ }^{50}$ The structures of these adducts are established. ${ }^{51-53}$ The formation of the $\mathrm{C} 8 \mathrm{-dG}$ adduct probably involves initial alkylation at N7-dG, followed by rearrangement. ${ }^{54}$ High sensitivity LC/ESI-MS ${ }^{55}$ has measured several adducts per $10^{7}$ nucleotides in animal tissues. ${ }^{19,56}$ The levels of $\mathrm{C} 8$ and $N^{2}$-dG IQ adducts measured in tissues of rats and primates using mass spectrometry 57,58 are in agreement with data obtained by ${ }^{32} \mathrm{P}$ postlabeling.

Heretofore, site-specific DNA adducts of HCAs have not been readily accessible. A synthesis of PhIP-adducted oligodeoxynucleotides involved reacting single-stranded DNA with the PhIP nitrenium ion. ${ }^{59}$ The low yield, coupled with complexities of purification, limited the approach to oligodeoxynucleotides containing a single dG. In the COS-7 site-specific mutagenesis system, ${ }^{60}$ if $\mathrm{dC}$ was at the $5^{\prime}$-flanking position to dG-C8 PhIP, incorporation of $\mathrm{dC}$, the correct base, was observed. However, $\mathrm{G} \rightarrow \mathrm{T}$ transversions, and lesser amounts of $\mathrm{G} \rightarrow \mathrm{A}$ transitions and $\mathrm{G} \rightarrow \mathrm{C}$ transversions, were detected. If the $\mathrm{dC} 5^{\prime}$-flanking base was replaced by $\mathrm{T}$, $\mathrm{dA}$, or $\mathrm{dG}$, the mutational spectra were similar, but greater mutational frequencies were observed with $\mathrm{dC}$ or dG than with dA $5^{\prime}$ to the adduct. Single-base deletions were detected only when dG or $\mathrm{T}$ flanked the adduct. Thus, dG-C8 PhIP was mutagenic, generating primarily $\mathrm{G} \rightarrow \mathrm{T}$ transversions. 61

A study of the C8-dG PhIP adduct in 5'-d(CCATCXCTACC)-3'.5'-d(GGTAGCGATGG)-3' represents the only conformational analysis of an HCA-adducted duplex. ${ }^{59}$ This yielded a base-displaced intercalated structure, in which the adducted $\mathrm{dG}$ was in the syn conformation and situated in the major groove. The C6-phenyl and N3-methyl groups protruded into the minor groove, widening it and compressing the major groove, resulting in DNA bending.

An efficient strategy for synthesis of C8-dG arylamine adducts involving the BuchwaldHartwig palladium-catalyzed $N$-arylation reaction of a protected 8-bromo-2'-dG derivative 
with arylamines facilitated preparation of the C8-IQ-adducted dG nucleoside, which was incorporated into oligodeoxynucleotides using phosphoramidite chemistry. ${ }^{62,63} \mathrm{~A}$ combination of thermal melting studies, and UV and circular dichrosim spectroscopy, led to the proposal of a base-displaced intercalated conformation at the $\mathrm{G}^{3}$-position of the $5^{\prime}$-d $\left(\mathrm{CG}^{1} \mathrm{G}^{2} \mathrm{CG}^{3} \mathrm{CC}\right)-3^{\prime}$ recognition site of the NarI enzyme. It was proposed that this was stabilized by a hydrogen bond between the quinoline nitrogen of IQ and the complementary cytosine. 63 In contrast, molecular mechanics analysis of the C8-dG IQ-modified duplex 5'-d $\left(\mathrm{G}^{1} \mathrm{G}^{2} \mathrm{CX}^{3} \mathrm{CCA}\right)-3^{\prime} \cdot 5^{\prime}$-d(TGGCGCC)-3' suggested that the favored conformation featured the modified dG in the syn conformation with IQ in the minor groove and directed $3^{\prime}$ with respect to the modified strand. ${ }^{64}$ This suggested that the base-displaced intercalated conformation was $\sim 10 \mathrm{kcal} / \mathrm{mol}$ higher in energy than the minor groove conformation. ${ }^{64}$ A study of the C8-dG IQ adduct at the nucleoside level confirmed that the adducted $\mathrm{dG}$ was in the syn conformation about the glycosyl bond. 53

This work presents a study of the C8-dG IQ adduct in $5^{\prime}$-d $\left(C^{1} T^{2} C^{3} G^{4} G^{5} C^{6} X^{7} C^{8} C^{9} A^{10} T^{11} C^{12}\right)-3^{\prime} \cdot 5^{\prime}-d$ $\left(\mathrm{G}^{13} \mathrm{~A}^{14} \mathrm{~T}^{15} \mathrm{G}^{16} \mathrm{G}^{17} \mathrm{C}^{18} \mathrm{G}^{19} \mathrm{C}^{20} \mathrm{C}^{21} \mathrm{G}^{22} \mathrm{~A}^{23} \mathrm{G}^{24}\right)-3^{\prime} ; X=8$-[(3-methyl-3H-imidazo[4,5-f] quinolin-2-yl)amino]-2'-deoxyguanosine, named the Nar1IQ3 sequence. It contains the $5^{\prime}$-d $\left(\mathrm{CG}^{1} \mathrm{G}^{2} \mathrm{CX}^{3} \mathrm{CC}\right)-3^{\prime}$ recognition site of the NarI restriction enzyme, in which the third guanine $\left(\mathrm{G}^{3}\right.$ in the NarI sequence and $\mathrm{X}^{7}$ in this study) represents a hot spot for $-2 \mathrm{bp}$ frameshifts (Chart 2 ). The results reveal a base-displaced intercalated structure. The adducted dG adopts a syn conformation about the glycosyl bond and extrudes into the major groove, the IQ moiety intercalates into the DNA, and the complementary dC extrudes from the helix. A hydrogen bond between the IQ quinoline nitrogen and the complementary $\mathrm{dC}^{63}$ is not observed.

\section{Materials and Methods}

\section{Sample Preparation}

The oligodeoxynucleotides 5'-d(CTCGGCGCCATC)-3' and 5'-d(GATGGCGCCGAG)-3' were obtained from the Midland Certified Reagent Company, purified by anion exchange chromatography. The oligodeoxynucleotide 5'-d(CTCGGCXCCATC)-3' was synthesized and purified as described. ${ }^{63}$ All oligodeoxynucleotides were characterized by MALDI-TOF mass spectrometry and enzymatic digestion, and their purities were assessed by capillary zone electrophoresis (CZE). Oligodeoxynucleotide duplexes were annealed at $70{ }^{\circ} \mathrm{C}$. Their stoichiometry was established by ${ }^{1} \mathrm{H}$ NMR. The duplexes were dissolved in $0.25 \mathrm{~mL}$ of buffer containing $0.1 \mathrm{M} \mathrm{NaCl}, 10 \mathrm{mM} \mathrm{NaH}_{2} \mathrm{PO}_{4}$, and $50 \mu \mathrm{M} \mathrm{Na} 2 \mathrm{EDTA}(\mathrm{pH}$ 7.0). The

oligodeoxynucleotide concentrations were $\sim 0.7 \mathrm{mM}$ using an extinction coefficient of $1.10 \times$ $10^{5} \mathrm{M}^{-1} \mathrm{~cm}^{-1}$ at $260 \mathrm{~nm} .{ }^{65}$

\section{NMR}

${ }^{1} \mathrm{H}$ NMR spectra were obtained at 500.13, 600.20, and 800.23 MHz. COSY spectra were collected at $15,20,25,30$, and $35{ }^{\circ} \mathrm{C}$ in $99.996 \% \mathrm{D}_{2} \mathrm{O} .{ }^{1} \mathrm{H}$ NOESY experiments in $\mathrm{D}_{2} \mathrm{O}$ were conducted at $15{ }^{\circ} \mathrm{C}$. To obtain distance restraints, spectra were recorded at mixing times of 150,200 , and $250 \mathrm{~ms}$ at the ${ }^{1} \mathrm{H}$ NMR frequency of $800.23 \mathrm{MHz}$. The data were recorded with 1024 real data points in the 11 dimension and 2048 real points in the $t 2$ dimension. The relaxation delay was $2 \mathrm{~s}$. The data in the $\mathrm{t} 1$ dimension were zero-filled to give a matrix of $2 \mathrm{~K}$ $\times 2 \mathrm{~K}$ real points. NOESY spectra for the exchangeable protons were recorded at $5{ }^{\circ} \mathrm{C}$, in $90: 10$ $\mathrm{H}_{2} \mathrm{O} / \mathrm{D}_{2} \mathrm{O}$, using the Watergate sequence ${ }^{66}$ for water suppression and a 250 -ms mixing time at a ${ }^{1} \mathrm{H}$ NMR frequency of $600.20 \mathrm{MHz}$. Chemical shifts of proton resonances were referenced to water. Double quantum-filtered ${ }^{1} \mathrm{H}$ correlation (DQF-COSY) ${ }^{67,68}$ and exclusive COSY (E-COSY) ${ }^{69}$ spectra were collected at $25^{\circ} \mathrm{C}$ at $500.13 \mathrm{MHz}$ and zero-filled to give a matrix of $1024 \times 2048$ real points. A skewed sine-bell square apodization function with a $90^{\circ}$ phase 
shift and a skew factor of 1.0 was used in both dimensions. ${ }^{1} \mathrm{H}-{ }^{31} \mathrm{P}$ HMBC spectra ${ }^{70,71}$ were obtained at $30{ }^{\circ} \mathrm{C}$. The data matrix was $256(\mathrm{t} 1) \times 2048(\mathrm{t} 2)$ complex points. The data were Fourier transformed after zero filling in the $\mathrm{t} 1$ dimension, resulting in a matrix size of 512 (D1) $\times 2048$ (D2) real points. Trimethyl phosphate was used as an external standard. NMR data were processed using the program FELIX2000 (Accelyris, Inc., San Diego, CA) on Silicon Graphics (Mountain View, CA) Octane workstations.

\section{Experimental Restraints}

(a) Distance Restraints-Footprints were drawn around cross-peaks for the NOESY spectrum measured at a mixing time of $250 \mathrm{~ms}$, using the program FELIX2000. Identical footprints were applied to the cross-peaks obtained at other mixing times. Cross-peak intensities were determined by volume integration. The intensities were combined with intensities generated from a complete relaxation matrix analysis of a starting DNA structure to generate a hybrid intensity matrix. ${ }^{72}$ The program MARDIGRAS (v. 5.2) 73,74 was used to refine the hybrid matrix by iteration. The molecular motion was assumed to be isotropic. The noise level was set at half the intensity of the weakest cross-peak. Calculations were performed using DNA starting structures generated using the program INSIGHT II (Accelyris, Inc.), and NOE intensities derived from experiments at three mixing times, and with three $\tau_{\mathrm{c}}$ values (2,3, and $4 \mathrm{~ns})$, yielding 18 sets of distances. Analysis of these data yielded experimental distance restraints and standard deviations used in restrained molecular dynamics calculations. For overlapped cross-peaks, the bounds on the distances were increased. The restraints were divided into four classes, reflecting the confidence level in the data.

(b) Torsion Angle Restraints-Deoxyribose pseudorotations were estimated by monitoring the ${ }^{3} J_{\mathrm{HH}}$ couplings of sugar protons. ${ }^{75}$ The $J_{\mathrm{H} 1^{\prime}-\mathrm{H} 2^{\prime}}$ and $J_{\mathrm{H} 1^{\prime}-\mathrm{H} 2^{\prime \prime}}$ couplings were measured from the E-COSY experiment, ${ }^{69}$ whereas the intensities of $J_{\mathrm{H} 2^{\prime \prime}-\mathrm{H} 3^{\prime}}$ and $J_{\mathrm{H} 3^{\prime}-\mathrm{H} 4^{\prime}}$ couplings were determined from the DQF-COSY experiment. The data were fit to curves relating the coupling constants to pseudorotation $(P)$, sugar pucker amplitude $(\phi)$, and the percentage S-type conformation. The pseudorotation and amplitude ranges were converted to the five dihedral angles $v_{0}$ to $v_{4}$.

\section{Restrained Molecular Dynamics}

Calculations were performed in vacuo using a simulated annealing protocol with the program X-PLOR. ${ }^{76}$ The force field was derived from CHARMM ${ }^{77}$ and adapted for nucleic acids. The empirical energy function treated hydrogens explicitly. The van der Waals energy term used the Lennard-Jones potential energy function. The electrostatic term used the Coulomb function, based on a full set of partial charges ( -1 per residue) and a distance-dependent dielectric constant of $4 r$. The nonbonded pair list was updated if any atom moved more than $0.5 \AA$, and the cutoff radius for nonbonded interactions was $11 \AA$. The effective energy function included terms describing distance and dihedral restraints, in the form of square-well potentials. Sets of rMD calculations for the unmodified and Nar1IQ3 duplexes, and different starting structures of Nar1IQ3 with IQ located in the minor groove (syn), major groove (anti), and intercalated position (syn), were considered. These were generated using INSIGHT II through modification at $\mathrm{G}^{7} \mathrm{C} 8$, followed by energy minimization using X-PLOR. Partial charges and atom types for IQ used for X-PLOR calculations were those obtained by Wu et al. ${ }^{64}$ Calculations were initiated by coupling to a heating bath, with a target temperature of $1100 \mathrm{~K}$. The force constants were $25 \mathrm{kcal} \mathrm{mol}^{-1} \AA^{-2}$ for empirical hydrogen bonding, $10 \mathrm{kcal} \mathrm{mol}^{-1} \AA^{-2}$ for torsion angle restraints, and 50,45, 40, and $35 \mathrm{kcal} \mathrm{mol}^{-1} \AA^{-2}$ for the four classes of NOE restraints. The target temperature was reached in $10 \mathrm{ps}$ and was maintained for $25 \mathrm{ps}$. The system was cooled to $300 \mathrm{~K}$ over $10 \mathrm{ps}$ and maintained at that temperature for $25 \mathrm{ps}$ of equilibrium dynamics. The force constants for the four classes of NOE restraints were scaled during $10 \mathrm{ps}$ of the heating period to $200,180,160$, and $140 \mathrm{kcal} \mathrm{mol}^{-1} \AA^{-2}$ in the order of confidence factor. These weights 
were maintained during the remainder of the heating period and for the first 5 ps of equilibrium dynamics. They were then scaled to $100,90,80$, and $70 \mathrm{kcal} / \mathrm{mol}^{-1} \AA^{-2}$ in the order of confidence factor. The torsion angle and base pair distance force constants were scaled to 180 and $100 \mathrm{kcal} \mathrm{mol}^{-1} \AA^{-2}$ during the same period as for the NOE restraints. They were scaled to 70 and $45 \mathrm{kcal} \mathrm{mol}^{-1} \AA^{-2}$, also at the same time as the NOE restraints. Coordinate sets were archived every $0.1 \mathrm{ps}$, and 41 structures from the last $4.1 \mathrm{ps}$ were averaged. These average rMD structures were subjected to 200 iterations of conjugate gradient energy minimization to obtain the final structures. Final structures were analyzed using X-PLOR to measure rmsd between the averaged and the converged structures. Back-calculation of NOE intensities from the emergent structures was performed using the program CORMA (v. 5.2) ${ }^{72} \mathrm{Helicoidal}$ parameters were examined using the program 3DNA. 78

\section{Results \\ NMR Spectroscopy}

(a) DNA Nonexchangeable Protons-For the Nar1IQ3 duplex, sequential NOE connectivities 79,80 were interrupted (Figure 1). The absence of a purine imidazole proton in the C8-IQ-dG adduct $\mathrm{X}^{7}$ precluded observation of the $\mathrm{C}^{6} \mathrm{H} 1^{\prime} \rightarrow \mathrm{X}^{7} \mathrm{H} 8$ and $\mathrm{X}^{7} \mathrm{H} 8 \rightarrow \mathrm{X}^{7} \mathrm{H} 1^{\prime}$ NOEs. The $\mathrm{X}^{7} \mathrm{H} 1^{\prime} \rightarrow \mathrm{C}^{8} \mathrm{H} 6 \mathrm{NOE}$ was of normal intensity. In the complementary strand, the $\mathrm{G}^{17} \mathrm{H} 1^{\prime} \rightarrow \mathrm{C}^{18} \mathrm{H} 6$ NOE was missing. The $\mathrm{C}^{18} \mathrm{H}^{\prime} \rightarrow \mathrm{G}^{19} \mathrm{H} 8$ sequential NOE was weak. $\mathrm{C}^{18}$ is the nucleotide opposite to $\mathrm{X}^{7}$ in the complementary strand of the Nar1IQ3 duplex. In the unmodified duplex, the $\mathrm{G}^{7} \mathrm{H} 8 \rightarrow \mathrm{G}^{7} \mathrm{H} 1^{\prime} \mathrm{NOE}$ was of normal intensity and all scalar crosspeaks between deoxyribose $\mathrm{H}^{\prime}$ and $\mathrm{H} 2^{\prime}, \mathrm{H} 2^{\prime \prime}$ protons were in the anticipated 1.6-2.8 ppm chemical-shift range. In contrast, for the Nar1IQ3 duplex, the $\mathrm{X}^{7} \mathrm{H} 2^{\prime}$ resonance shifted downfield to $3.61 \mathrm{ppm}$. This was characteristic of a syn $\mathrm{dG}$ orientation at $\mathrm{X}^{7}$. Complete sets of sequential NOEs were observed for both strands of the unmodified duplex (Figure S1 in the Supporting Information). The resonance assignments for the nonexchangeable protons of the Nar1IQ3 and unmodified duplexes are found in Tables S1 and S2 of the Supporting Information.

(b) DNA Exchangeable Protons-The presence of the C8-dG IQ adduct resulted in chemical-shift dispersion of the imino proton resonances in the downfield region of the ${ }^{1} \mathrm{H}$ spectrum (Figure 2; Figure S2 in the Supporting Information shows an expanded contour plot of the imino proton resonances of the unmodified duplex). Whereas for the unmodified duplex the imino resonances arising from $G^{4}, G^{5}, G^{7}, G^{16}, G^{17}$, and $G^{22}$ were observed between 13 and $13.4 \mathrm{ppm}$, for the Nar1IQ3 duplex, these imino protons resonated between 9.6 and 13.4 $\mathrm{ppm}$. The imino protons of the Nar1IQ3 duplex were assigned from NOEs between adjacent base pairs and NOEs to their corresponding base-paired amino protons. ${ }^{81}$ Interruptions in the NOEs between Watson-Crick hydrogen-bonded amino and imino protons of the Nar1IQ3 duplex occurred between base pairs $C^{6} \cdot G^{19}$ and $X^{7} \cdot C^{18}$ and base pairs $X^{7} \cdot C^{18}$ and $C^{8} \cdot G^{17}$. All other sequential NOEs were observed. The $X^{7}$ and $G^{17} \mathrm{~N} 1 \mathrm{H}$ resonances shifted upfield and were observed at 9.6 and $11.7 \mathrm{ppm}$, respectively. The $\mathrm{X}^{7} \mathrm{~N} 1 \mathrm{H}$ proton exhibited NOEs to the $\mathrm{X}^{7} \mathrm{NH}_{2}$ protons. The amino protons resonated at 6.67 and $8.83 \mathrm{ppm}$, respectively. At the 5'adjacent $\mathrm{G}^{6} \cdot \mathrm{C}^{19}$ base pair, $\mathrm{G}^{19} \mathrm{~N} 1 \mathrm{H}$ showed NOEs to the $\mathrm{C}^{6} \mathrm{NH}_{2}$ protons and to $\mathrm{C}^{6} \mathrm{H} 5$. At the $3^{\text {'-adjacent }} \mathrm{C}^{8} \cdot \mathrm{G}^{17}$ base pair, $\mathrm{G}^{17} \mathrm{~N} 1 \mathrm{H}$ showed NOEs to the $\mathrm{C}^{8} \mathrm{NH}_{2}$ protons and to $\mathrm{C}^{8} \mathrm{H} 5$. The $\mathrm{T}^{2} \mathrm{~N} 3 \mathrm{H} \rightarrow \mathrm{A}^{23} \mathrm{H} 2$ and $\mathrm{T}^{11} \mathrm{~N} 3 \mathrm{H} \rightarrow \mathrm{A}^{10} \mathrm{H} 2$ NOEs were detected. The resonance assignments for the nonexchangeable protons of the Nar1IQ3 and nonmodified duplexes are found in Table S3 of the Supporting Information.

(c) IQ Protons-The resonance assignments of the IQ protons were achieved using a combination of COSY and NOESY spectra, collected at $5{ }^{\circ} \mathrm{C}$ intervals between 15 and $45^{\circ} \mathrm{C}$. The COSY IQ H4A $\rightarrow$ H5A cross-peak was observed at all of these temperatures. However, 
the small scalar coupling between the IQ H8A and H7A protons was not observed below $25^{\circ}$ $\mathrm{C}$, presumably due to line broadening at the lower temperatures. The COSY cross-peaks between the IQ protons also broadened above $35^{\circ} \mathrm{C}$. This could be due to thermal melting of the duplex as the temperature was increased and might also reflect conformational exchange at higher temperatures. Figure 3 compares the NOESY spectrum collected at $15{ }^{\circ} \mathrm{C}$ with a magnitude COSY spectrum collected at $30^{\circ} \mathrm{C}$. The IQ H4A proton was assigned at $7.28 \mathrm{ppm}$ on the basis of a cross-peak to the IQ methyl protons in the NOESY spectrum. The IQ H5A proton resonance was assigned at $7.05 \mathrm{ppm}$ on the basis of its scalar coupling to $\mathrm{H} 4 \mathrm{~A}$. The IQ $\mathrm{H} 7 \mathrm{~A}, \mathrm{H} 8 \mathrm{~A}$, and H9A proton resonances were distinguished on the basis of comparison of scalar couplings and chemical shifts to those of pyridine. The resonances at 8.06 and $7.79 \mathrm{ppm}$ were assigned to the H7A and H9A protons, and that at $6.70 \mathrm{ppm}$ was assigned to the H8A proton. The H7A resonance exhibited broadening attributed to the pyridinyl nitrogen.

\section{IQ-DNA NOES}

There were 24 NOEs observed between the IQ moiety and DNA protons (Figure 4, and Table $\mathrm{S} 4$ in the Supporting Information). The IQ H4A proton exhibited NOEs to $\mathrm{G}^{19} \mathrm{H}^{\prime}$ and $\mathrm{H} 5^{\prime}$, and to $\mathrm{G}^{17} \mathrm{~N} 1 \mathrm{H}$. The IQ H5A proton exhibited NOEs to $\mathrm{G}^{19} \mathrm{H1}^{\prime}, \mathrm{H} 5^{\prime}$, and $\mathrm{H} 5^{\prime \prime}, \mathrm{G}^{17} \mathrm{~N} 1 \mathrm{H}$ (weak), and $\mathrm{C}^{18} \mathrm{H} 3^{\prime}$ and $\mathrm{H}^{\prime}$ (weak). The IQ H9A proton exhibited NOEs to $\mathrm{G}^{17} \mathrm{H}^{\prime}, \mathrm{H} 2^{\prime}$, $\mathrm{H} 2^{\prime \prime}$, and $\mathrm{H} 8$, and to $\mathrm{C}^{18} \mathrm{H}^{\prime}, \mathrm{H} 3^{\prime}, \mathrm{H}^{\prime}, \mathrm{H}^{\prime}$, and H5". The IQ methyl protons exhibited NOEs to $\mathrm{X}^{7} \mathrm{H} 1^{\prime}, \mathrm{C}^{8} \mathrm{H} 6, \mathrm{G}^{17} \mathrm{~N} 1 \mathrm{H}, \mathrm{G}^{19} \mathrm{H} 8$, and $\mathrm{G}^{19} \mathrm{~N} 1 \mathrm{H}$.

\section{Torsion Angle Analysis}

The glycosyl torsion angle, $\chi$, was evaluated by inspection of chemical shift data at the deoxyribose $\mathrm{H} 2^{\prime}, \mathrm{H} 2$ " protons. ${ }^{82,83}$ Expanded DQF-COSY plots identifying scalar couplings between deoxyribose $\mathrm{H} 1^{\prime}(5.0-6.7 \mathrm{ppm})$ and $\mathrm{H} 2^{\prime}, \mathrm{H} 2^{\prime \prime}$ protons in the unmodified and the Nar1IQ3 duplexes are shown in Figure 5. For the Nar1IQ3 duplex, the $\mathrm{X}^{7} \mathrm{H} 2^{\prime}$ resonance shifted downfield to $3.61 \mathrm{ppm}$. This was characteristic of the syn $\mathrm{dG}$ orientation at $\mathrm{X}^{7}$. Analysis of DQF-COSY spectra suggested that all of the pyrimidine pseudorotation values were in the $\mathrm{Cl}^{\prime}$ exo range of $P=126 \pm 18^{\circ}$, and all of the purines in the center 10 base pairs had pseudorotation values in the $\mathrm{C}^{\prime}$-endo range of $P=162 \pm 18^{\circ}$. The sugar pucker of $\mathrm{X}^{7}$ was in $\mathrm{C}^{\prime}$-endo region. The glycosyl torsion angles and the deoxyribose pseudorotations for the Nar1IQ3 and unmodified duplexes are found in Table S5 of the Supporting Information.

Figure 6 shows the ${ }^{31} \mathrm{P}$ HMBC correlation spectrum for the Nar1IQ3 duplex and its unmodified counterpart, and the assignments of $\mathrm{P}^{6}, \mathrm{P}^{7}, \mathrm{P}^{17}$, and $\mathrm{P}^{18}$, the phosphodiester linkages $5^{\prime}$ - and $3^{\prime}$ to the IQ adduct in the modified and complementary strands, respectively. The $\mathrm{C}^{8}$-dG IQ adduct dispersed these four ${ }^{31} \mathrm{P}$ resonances, with the most significant change occurring at $\mathrm{P}^{6}$, the phosphodiester $5^{\prime}$ to $\mathrm{X}^{7}$ in the modified strand. The downfield ${ }^{31} \mathrm{P}$ chemical shift at $\mathrm{P}^{6}$ presumably reflects conformational perturbations associated with the $\mathrm{P}^{6}$ phosphodiester. ${ }^{84}$ The small differences observed for ${ }^{31} \mathrm{P}$ chemical shifts for $\mathrm{P}^{17}$ and $\mathrm{P}^{18}$ suggested that the phosphodiesters opposite to $\mathrm{X}^{7}$ in the complementary strand were less perturbed. The carcinogen-base linkage site at $\mathrm{X}^{7}$ residue is defined by the torsion angles $\alpha^{\prime}$ (N9-C8-N[IQ]$\mathrm{C} 2[\mathrm{IQ}]$ ) and $\beta^{\prime}$ (C8-N[IQ]-C2[IQ]-N3-[IQ]). The absence of an NOE between the IQ NH and methyl protons suggested that the $\beta^{\prime}$ torsion angle must be in an eclipsed conformation, placing these protons far apart. Molecular modeling confirmed four stable syn conformations with $\alpha^{\prime}$ and $\beta^{\prime}$ at 0 and $180^{\circ}$ in all combinations.

\section{Chemical-Shift Perturbations}

The ${ }^{1} \mathrm{H}$ NMR chemical shifts of the Nar1IQ3 dodecamer were compared with those of the unmodified duplex (Figure 7). The largest perturbations were observed for the aromatic and anomeric protons of $\mathrm{C}^{18}$ in the complementary strand, opposite to the adduct. Smaller 
perturbations were also observed for the $\mathrm{G}^{17} \mathrm{H} 8, \mathrm{G}^{19} \mathrm{H} 8$ and $\mathrm{H} 1^{\prime}, \mathrm{C}^{6} \mathrm{H} 6$ and $\mathrm{H}^{\prime}, \mathrm{X}^{7} \mathrm{H} 1^{\prime}$, and $\mathrm{C}^{8} \mathrm{H} 6$ and $\mathrm{H} 1^{\prime}$ resonances.

\section{Structural Refinement}

For the Nar1IQ3 duplex, a total of 488 NOE-based distance restraints were obtained, consisting of 148 inter- and 340 intra-nucleotide distances. They included 24 DNA-IQ distances. For the unmodified duplex, a total of 463 NOE-based distance restraints were obtained, consisting of 138 inter-and 325 intra-nucleotide distances. For the Nar1IQ3 duplex, the pyrimidine pseudorotation values were restrained in the $\mathrm{C}^{\prime}$-exo range of $P=126 \pm 18^{\circ}$, and the purines in the center 10 base pairs were restrained with pseudorotation values in the $\mathrm{C} 2{ }^{\prime}$-endo range of $P=162 \pm 18^{\circ}$. No backbone torsion angle restraints were used for the modified strand at the lesion site. Elsewhere, the backbone angles $\alpha, \beta$, and $\xi$ were restrained to $-60 \pm 30^{\circ}, 180$ $\pm 30^{\circ}$, and $-90 \pm 30^{\circ}$, respectively, to allow both A- and B-like geometry. ${ }^{85}$ No empirical base-pairing restraints were used at the lesion site. Elsewhere, empirical base-pair planarity and Watson-Crick hydrogen-bonding restraints were used. These were consistent with crystallographic data. ${ }^{86}$ Their inclusion was based on data that showed that DNA maintained Watson-Crick base pairing.

The restrained molecular dynamics calculation employed a simulated annealing protocol. This began with a searching strategy guided by intermolecular IQ-DNA restraints. The DNA starting conformation was B-like except for the syn glycosyl torsion angle at $\mathrm{X}^{7}$. The orientation space was searched with 16 energy minimization trials in which the IQ angles $\alpha^{\prime}$ and $\beta^{\prime}$ (Chart 2) were started at $0,90,180$, and $270^{\circ}$ in all combinations. This generated four stable conformations with the glycosyl bond in the syn conformation and the angles $\alpha^{\prime}$ and $\beta^{\prime}$ at 0 and $180^{\circ}$. For the conformations with $\alpha^{\prime} \approx 0^{\circ}$ IQ oriented in minor groove, while for conformations with $\alpha^{\prime} \approx 180^{\circ}$ IQ intercalated. These were checked with respect to NOE violations. One exhibited the best fit to the NOE data of the Nar1IQ3 duplex.

Figure 8 shows a stereoview of an ensemble of 10 structures obtained from randomly seeded calculations. Their precision was determined by pairwise rmsd measurements. These exhibited a maximum pairwise rmsd of $0.68 \AA$, suggesting convergence. Figure S3 of the Supporting Information shows the corresponding results for the unmodified duplex.

The accuracy of the refinement was determined by calculation of NOE intensities from the emergent structures using the program CORMA (v. 5.2) ${ }^{72}$ (Figure 9). The overall sixth root residual $\mathrm{R}_{1}^{x}$ for structures of the Nar1IQ3 duplex was $8.1 \times 10^{-2}$. Figure S4 of the Supporting Information shows corresponding data for the unmodified duplex. For the Nar1IQ3 duplex, inter-and intraresidue $\mathrm{R}_{1}{ }^{x}$ values were on the order of $10 \%$. At the adduct site, the residuals were $6.2,11,5.2$, and $6.1\left(\times 10^{-2}\right)$ for $\mathrm{C}^{8}, \mathrm{G}^{17}, \mathrm{C}^{18}$, and $\mathrm{G}^{19}$, respectively. The structural statistics are found in Table 1.

\section{Solution Conformation}

The IQ moiety was inserted into the helix with the modified guanine and its complement $\mathrm{C}^{18}$ displaced in the major groove. Views normal to the helix axis and looking into the major groove of the central $5^{\prime}-\mathrm{d}\left(\mathrm{C}^{6} \mathrm{X}^{7} \mathrm{C}^{8}\right)-3^{\prime} \cdot 5^{\prime}-\mathrm{d}\left(\mathrm{G}^{17} \mathrm{C}^{18} \mathrm{G}^{19}\right)-3^{\prime}$ segments of the unmodified and Nar1IQ3 duplexes are shown in Figure 10. The IQ ring inserted between the $\mathrm{C}^{6} \cdot \mathrm{G}^{19}$ and $\mathrm{C}^{8} \cdot \mathrm{G}^{17}$ base pairs by displacing the modified guanine of the syn $\mathrm{X}^{7}$ nucleotide into the major groove. The glycosyl torsion angle $\chi\left(\mathrm{O}^{\prime}-\mathrm{C} 1^{\prime}-\mathrm{N} 9-\mathrm{C} 4\right)$ of the $\mathrm{X}^{7}$ residue was calculated as 85 $\pm 10^{\circ}$.

The IQ methyl group faced into the helix. This placed the IQ H4A and H5A protons facing into the duplex, toward $\mathrm{C}^{18}$ and $\mathrm{G}^{19}$ in the complementary strand, whereas the IQ H7A, H8A, 
and $\mathrm{H} 9 \mathrm{~A}$ protons faced into the major groove in the vicinity of $\mathrm{G}^{17}$ and $\mathrm{C}^{18}$ in the complementary strand. One proton of the $\mathrm{X}^{7}$ exocyclic amino group was close to oxygen at the phosphodiester linkage $\mathrm{P}^{6}$ between $\mathrm{C}^{6}$ and $\mathrm{X}^{7}$. This yielded a $\mathrm{N}-\mathrm{H} \cdots \mathrm{O}$ distance of $2.8 \AA$, suggesting the formation of a hydrogen bond. Opposite to $\mathrm{X}^{7}$, the insertion of the IQ ring into the helix resulted in the displacement of $\mathrm{C}^{18}$ into the major groove.

Views looking down the helix axis of the $5^{\prime}-\mathrm{d}\left(\mathrm{C}^{6} \mathrm{X}^{7} \mathrm{C}^{8}\right)-3^{\prime} \cdot 5^{\prime}-\mathrm{d}\left(\mathrm{G}^{17} \mathrm{C}^{18} \mathrm{G}^{19}\right)-3^{\prime}$ segment are shown in Figure 11. The primary interaction involved base pair $\mathrm{C}^{8} \cdot \mathrm{G}^{17}$, the $3^{\prime}$-neighboring base pair with respect to $X^{7}$. The $G^{17}$ imino proton was shielded by the IQ ring. However, the calculations suggested that the IQ ring tilted with respect to the DNA base pairs, presumably reducing stacking with base pairs $C^{6} \cdot G^{19}$ and $C^{8} \cdot G^{17}$. This might be attributed to steric hindrance from the IQ methyl group. This tilt was defined by the IQ torsion angle $\beta^{\prime}$ which was measured from the refined structures as $-23 \pm 8^{\circ}$. The IQ torsion angle $\alpha^{\prime}$ was calculated as $158 \pm 7^{\circ}$, resulting in the amine linkage of the IQ adduct being in plane with the C8-modified dG. The calculated glycosyl torsion angles and sugar pseudorotation $P$ of the Nar1IQ3 duplex are found in Table S5 in the Supporting Information. The presence of the C8-dG IQ adduct opposite $\mathrm{dC}$ resulted in a bend at the adduct site of $23 \pm 5^{\circ}$, and helical twist angles of $-56 \pm$ $3^{\circ}$ and $-76 \pm 3^{\circ}$ for base pair steps $\mathrm{C}^{6} \rightarrow \mathrm{X}^{7}$ and $\mathrm{X}^{7} \rightarrow \mathrm{C}^{8}$, respectively.

\section{Discussion}

The synthesis of site-specific C8-dG arylamine oligodeoxy-nucleotide adducts 62,63 enabled high-resolution conformational studies of a site-specific C8-dG IQ adduct in the Nar1IQ3 duplex. The conformation of the C8-dG IQ adduct in DNA has been of interest because this adduct represents one of the most mutagenic HCAs found in the human diet. Both basedisplaced insertion 63 and minor groove ${ }^{64}$ conformations have been proposed for the $\mathrm{C} 8 \mathrm{-dG}$ IQ DNA adduct, and indeed, the energetic differences between the two proposed conformations are likely to be modest and dependent upon sequence context.

\section{Base-Displaced Insertion of the IQ Adduct}

The present studies reveal that for the Nar1IQ3 duplex, in which the C8-dG IQ adduct is located at position $\mathrm{G}^{3}$ of the $5^{\prime}-\mathrm{d}\left(\mathrm{CG}^{1} \mathrm{G}^{2} \mathrm{CG}^{3}-\mathrm{CC}\right)-3^{\prime}$ recognition site of the NarI enzyme, the basedisplaced insertion conformation is favored. The key evidence supporting the conclusion that the $\mathrm{X}^{7}$ glycosyl torsion angle $\chi$ was in the syn conformation was the downfield chemical shift for the $\mathrm{X}^{7} \mathrm{H} 2^{\prime}$ resonance, observed at $3.61 \mathrm{ppm}$ (Figure 5). This downfield shift of the H2' resonance is a characteristic marker of the syn conformation of $\mathrm{dG}$ in modified duplexes. ${ }^{82}$, 83 This corroborated work showing that the dG-C8 IQ adduct was in the syn conformation at the nucleoside level. ${ }^{53}$

Rotation of the glycosyl bond into the syn conformation at $\mathrm{X}^{7}$ placed the Watson-Crick hydrogen bonding edge of the modified $\mathrm{dG}$ into the major groove. The $\mathrm{X}^{7}$ imino and amino protons were exposed to solvent. Displacement of the modified dG into the major groove was consistent with the observed $\mathrm{X}^{7}$ imino proton chemical shift of $9.6 \mathrm{ppm}$, which was to the high field of the imino protons of other G.C base pairs. One proton of the amino group of the modified guanine was within $2.8 \AA$ of the oxygen at the phosphodiester linkage $\mathrm{P}^{6}$ between $\mathrm{C}^{6}$ and $\mathrm{X}^{7}$. This suggested the potential for formation of a hydrogen bond that was consistent with the $\mathrm{X}^{7}$ amino proton chemical shifts of 6.67 and $8.83 \mathrm{ppm}$ (Figure 2). This hydrogen bond might cause the local electrostatic potential at phosphodiester linkage $\mathrm{P}^{6}$ to be perturbed. This notion was supported by the significant ${ }^{31} \mathrm{P}$ chemical shift perturbation observed at $\mathrm{P}^{6}$ (Figure 7). A strong $\mathrm{X}^{7} \mathrm{H} 1^{\prime} \rightarrow \mathrm{C}^{8} \mathrm{H} 6$ NOE for the $\mathrm{X}^{7} \rightarrow \mathrm{C}^{8}$ base step (Figure 1) was consistent with a separation between these protons of $3.0 \pm 0.4 \AA$, as measured in the intensity-refined structures of the duplex. 
Evidence supporting insertion of the IQ ring between $C^{6} \cdot G^{19}$ and $C^{8} \cdot G^{17}$ base pairs included the upfield shift of the $\mathrm{G}^{17}$ imino proton as a result of stacking with the intercalated IQ ring (Figure 2). The IQ ring stacked primarily with $\mathrm{G}^{17}$ and $\mathrm{G}^{19}$ (Figure 11). There was no stacking between IQ and $\mathrm{C}^{6}$ or $\mathrm{C}^{8}$. The observed NOEs (Table $\mathrm{S} 4$ in the Supporting Information) were consistent with the IQ H4A and H5A protons being directed toward $\mathrm{C}^{18}$ and $\mathrm{G}^{19}$ in the complementary strand, and the IQ H7A, H8A, and H9A protons being directed toward $\mathrm{G}^{17}$ and $\mathrm{C}^{18}$ in the complementary strand (Figure 10). The IQ methyl protons were closer to $\mathrm{G}^{19}$ than to $\mathrm{C}^{8}$ (Figure 10), also consistent with the observed NOEs (Table S4). The absence of an NOE between the IQ amine and methyl protons was attributed to rapid exchange of the amine proton with solvent.

On the basis of a decrease of the IQ absorption, Elmquist et al. ${ }^{63}$ suggested a hydrogen bond between the IQ quinoline nitrogen and the exocyclic amine of complementary base $\mathrm{C}^{18}$. They proposed that this might stabilize the base-displaced insertion conformation with respect to a minor groove conformation. Spectroscopic evidence for this hydrogen bond was not observed. A series of rMD calculations that included this hydrogen bond as a restraint yielded structures that did not agree with the experimental NOEs. Instead, $\mathrm{C}^{18}$ was displaced into the major groove (Figure 10). This displacement of $\mathrm{C}^{18}$ resulted in a break in the ${ }^{1} \mathrm{H}$ sequential NOE connectivity at the $\mathrm{G}^{17} \rightarrow \mathrm{C}^{18}$ step (Figure 1). This distance was predicted to be $7.9 \pm 0.4 \AA$ in the refined structures. The $\mathrm{C}^{18}$ amino proton resonances were not observed. This was consistent with the displacement of $\mathrm{C}^{18}$ into the major groove. These proton resonances were presumably broadened due to an intermediate rate of rotation about the $\mathrm{C} 4-\mathrm{N}^{4}$ bond and exchange with solvent.

The present results revealing a base-displaced insertion structure of the C8-dG IQ adduct in the Nar1IQ3 duplex differ from the predictions of a molecular mechanics study on the duplex $5^{\prime}-\mathrm{d}\left(\mathrm{G}^{1} \mathrm{G}^{2} \mathrm{C} X^{3} \mathrm{CCA}\right)-3^{\prime} \cdot 5^{\prime}$-d(TGGCGCC)- $3^{\prime} .{ }^{64}$ The latter study predicted small energetic differences between groove-bound and base-displaced intercalated conformations of the C8dG IQ adduct. The favored conformation as predicted by molecular mechanics contained the modified dG in the syn conformation about the glycosyl bond with the IQ in the minor groove and directed in the $3^{\prime}$ direction with respect to the modified strand. The calculations suggested that the base-displaced intercalated structure was $\sim 10 \mathrm{kcal} / \mathrm{mol}$ higher in energy than the minor groove structure.

\section{Sequence Dependence}

The small energetic differences predicted by the molecular mechanics calculations ${ }^{64}$ suggest that the conformations of C8-dG IQ adducts in duplex DNA are likely to be influenced by DNA sequence. Differing conformations may be responsible for increased genotoxicity in hotspot sequences. Sequence analysis of HCA-induced mutations in SOS-induced bacteria revealed the majority of mutations in the lac $Z$ gene were clustered in hotspots involving iterated Gs. ${ }^{87}$ The $5^{\prime}-\mathrm{d}\left(\mathrm{CG}^{1} \mathrm{G}^{2} \mathrm{CX}^{3} \mathrm{CC}\right)-3^{\prime}$ recognition sequence of the NarI restriction enzyme examined herein represents a hot spot for -2 frameshift mutations ${ }^{82}$ at $\mathrm{G}^{3}$ when $\mathrm{G}^{3}$ is modified by aromatic amines. ${ }^{88-96}$ Elmquist et al. ${ }^{63}$ examined the properties of the C8-dG IQ adduct located in the 5'-d(GGCAGXTGGTG)-3'.5'-d(CACCACCTGCC)-3' duplex, bearing codon 12 of the human $N$-ras protooncogene (underlined). Utilizing a combination of thermal UV melting studies, UV spectroscopy, and circular dichroism, they concluded that the C8-dG IQ adduct adopted a groove-bound conformation in the ras 12 sequence, similar to that predicted by $\mathrm{Wu}$ et al. ${ }^{64}$ It will be of interest to examine the sequence dependence of the C8-dG IQ adduct in greater detail. 


\section{Comparison with the C8-dG PhIP Adduct}

The solution structure of the C8-dG PhIP adduct was reported in 5'-d(CCATCXCTACC)- $3^{\prime} \cdot 5^{\prime}$ d(GGTAGCGATGG)-3' ${ }^{59}$ The PhIP-modified duplex with 5'-d(CXC)-3' sequence adopted a conformation similar to that of the C8-dG IQ adduct in the Nar1IQ3 sequence. In the PhIPmodified duplex, the C8-dG PhIP adduct existed with the modified dG in the syn conformation and displaced into the major groove. The complementary $\mathrm{dC}$ was displaced into the major groove. The IP ring inserted into the duplex, stacking with the flanking $\mathrm{G}^{18}$ purine and the $\mathrm{C}^{5}$ and $\mathrm{G}^{16}$ rings. However, the out-of-plane geometry of the phenyl ring with respect to the IP ring in the PhIP adduct contributed to a greater unwinding and twisting of the helix as compared to the C8-dG IQ adduct. The PhIP phenyl ring was inclined out-of-plane relative to the IP ring, rotating rapidly, precluding stacking with the flanking bases. Additionally, the PhIP methyl group was positioned toward the modified strand, directed toward the minor groove edge of the DNA, whereas in the Nar1IQ3 duplex, the IQ methyl group was stacked between the flanking bases. Corresponding to the above differences, the PhIP-dG linkage site was defined by torsion angles $\alpha^{\prime}$ and $\beta^{\prime}$ by $221.3 \pm 3.0$ and $132.5 \pm 8.0^{\circ}$.

\section{Comparison with Aminofluorene and Acetyl-amino-fluorene C8-dG Adducts}

Adducts arising from the arylamines 2-aminofluorene (AF) and $\mathrm{N}$-acetyl-2-aminofluorene (AAF) were extensively studied. ${ }^{10}$ The biological responses to the AF and AAF lesions differed, ${ }^{97}$ although they were structurally similar. In bacterial mutagenesis assays, the AAF adduct gave -1 and -2 frameshift mutations, $, 88,98-101$ whereas base-pair substitutions were largely observed for AF. Both the C8-dG IQ (this work) and C8-dG AAF adducts 102 exhibited single base-displaced inserted structures when placed opposite $\mathrm{dC}$ in the $5^{\prime}-\mathrm{d}(\mathrm{CXC})-3^{\prime}$ context. NMR data for the C8-dG AF adduct in the Nar1IQ3 sequence was equivocal due to a mixture of conformers. ${ }^{103}$ An AF-intercalated conformer with the modified dG in the syn conformation and displaced with the 5 '-flanking $\mathrm{dC}$ residue into the major groove was reported for the C8-dG AF adduct opposite -2 base deletion in the Nar1IQ3 sequence. ${ }^{104}$

\section{Structure-Activity Relationships}

The $5^{\prime}-\mathrm{d}\left(\mathrm{CG}^{1} \mathrm{G}^{2} \mathrm{CG}^{3} \mathrm{CC}\right)-3^{\prime}$ NarI sequence represents the strongest known hotspot for frameshift mutagenesis. ${ }^{88,105}$ Within the NarI sequence, the propensity for frameshift mutagenesis is sequence-dependent. These mutations occur following adduct formation at the $\mathrm{G}^{3}$ but not the $\mathrm{G}^{1}$ or $\mathrm{G}^{2}$ positions. ${ }^{105,106} \mathrm{~A}$ single $\mathrm{C} 8-\mathrm{dG}$ acetylaminofluorene adduct located at position $\mathrm{G}^{3}$ induced $-2 \mathrm{bp}$ frameshifts more than $10^{7}$-fold over background mutagenesis in Escherichia coli. ${ }^{107}$ In a study using site-specifically adducted oligonucleotides, it was found that AAF at the $\mathrm{G}^{3}$-position of the NarI sequence gave almost exclusively two-base deletion when replicated in bacteria, while giving largely base-pair substitution at the $\mathrm{G}^{1}$ and $\mathrm{G}^{2}$ positions. In COS-7 cells, the C8-AAF adduct gave base-pair substitution at all three positions. 108 The -2 bp frameshift mutations induced at position $\mathrm{G}^{3}$ in the $\mathrm{NarI}$ sequence by the aromatic amine $\mathrm{AAF}^{109,110}$ arose via AAF-induced stabilization of a transient strand slippage intermediate during trans-lesion replication, ${ }^{110-112}$ and it is thought that the $-2 \mathrm{bp}$ frameshifts induced by the PhIP C8-dG adduct arise via the same mechanism. ${ }^{61}$ Crystallographic analysis of the bypass polymerase Dpo4 from Sulfolobus solfataricus involving complexes with damaged DNA templates supports the notion that error-prone lesion bypass can involve the formation of transient slippage intermediates. ${ }^{113-115}$ Koffel-Schwartz and Fuchs demonstrated that the dinucleotide repeat GCGC was essential for the $-2 \mathrm{bp}$ frameshifts in the NarI sequence, whereas the flanking nucleotides $N_{\mathrm{a}} \mathrm{GCGC} N_{\mathrm{b}}$, particularly $\mathrm{N}_{\mathrm{b}}$, modulated the relative mutagenic strength of the sequence. ${ }^{107}$ In the case of AAF, it is thought that the $3^{\prime}-$ neighboring base $\mathrm{N}_{\mathrm{b}}$ forms favorable stacking interactions with the fluorene ring that stabilize the transient two-base strand slippage intermediate. 116 
The base-displaced intercalated structure may also play a role in modulating the repair of the C8-dG IQ adduct. Turesky et al. ${ }^{117}$ proposed that differences in the accumulation and rates of removal of C8-dG IQ and N2-dG IQ adducts in rodents and nonhuman primates may be attributable to differences in conformation about the glycosyl bond in the two classes of adducts. Adducts in the syn form are proposed to create greater distortions of the DNA duplex and, hence, be more easily recognized and excised. In contrast, adducts in the anti conformation are proposed to be more refractory toward repair. Turesky et al. ${ }^{117}$ observed a preferential removal of the C8-dG IQ adduct, whereas the N2-dG IQ adduct was more persistent. The latter existed in the anti conformation about the glycosyl bond at the nucleoside level.

\section{Structural Coordinates Available}

For the unmodified Nar1 duplex, the PDB ID code is 2HKB. For the IQ-modified Nar1IQ3 duplex, the PDB ID code is $2 \mathrm{HKC}$.

\section{Supplementary Material}

Refer to Web version on PubMed Central for supplementary material.

\section{Acknowledgment}

We thank Drs. Thomas M. and Constance M. Harris for helpful discussions and suggestions. We thank Ms. Pamela Tamura and Ms. Albena Kozekova for assistance with the oligodeoxynucleotide synthesis and mass spectrometry and Mr. Markus Voehler for assistance with NMR experiments. This work was supported by NIH Grant CA-55678 (M.P.S.). The Vanderbilt Center for Molecular Toxicology is funded by a center grant from the National Institute of Environmental Health Sciences (ES-00267). J.S.S. was supported by NIH pre-doctoral traineeship ES-07028. Funding for the NMR spectrometers was supplied by NIH Grants RR-05805, ES-00267, and Vanderbilt University.

\section{References}

1. Wakabayashi K, Nagao M, Esumi H, Sugimura T. Cancer Res 1992;52:2092-2098.

2. Layton DW, Bogen KT, Knize MG, Hatch FT, Johnson VM, Felton JS. Carcinogenesis 1995;16:39_ 52. [PubMed: 7834804]

3. Sugimura T. Mutat. Res 1997;376:211-219. [PubMed: 9202758]

4. Sugimura T, Wakabayashi K, Nakagama H, Nagao M. Cancer Sci 2004;95:290-299. [PubMed: 15072585]

5. Kataoka H, Nishioka S, Kobayashi M, Hanaoka T, Tsugane S. Bull. Environ. Contam. Toxicol 2002;69:682-689. [PubMed: 12375117]

6. Felton JS, Knize MG, Salmon CP, Malfatti MA, Kulp KS. Environ. Mol. Mutagen 2002;39:112-118. [PubMed: 11921178]

7. Kobayashi M, Hanaoka T, Nishioka S, Kataoka H, Tsugane S. Mutat. Res 2002;506-507:233-241.

8. Ushiyama H, Wakabayashi K, Hirose M, Itoh H, Sugimura T, Nagao M. Carcinogenesis 1991;12:14171422. [PubMed: 1907222]

9. Ohgaki H, Hasegawa H, Kato T, Suenaga M, Ubukata M, Sato S, Takayama S, Sugimura T. Environ. Health Perspect 1986;67:129-134. [PubMed: 3757948]

10. Heflich RH, Neft RE. Mutat. Res 1994;318:73-114. [PubMed: 7521935]

11. Thorgeirsson UP, Snyderwine EG, Gomez DE, Adamson RH. In Vivo 1996;10:145-152. [PubMed: 8744793]

12. Ohgaki H, Kusama K, Matsukura N, Morino K, Hasegawa H, Sato S, Takayama S, Sugimura T. Carcinogenesis 1984;5:921-924. [PubMed: 6733854]

13. Takayama S, Nakatsuru Y, Masuda M, Ohgaki H, Sato S, Sugimura T. Gann 1984;75:467-470. [PubMed: 6468834]

14. Tanaka T, Barnes WS, Williams GM, Weisburger JH. Jpn. J. Cancer Res 1985;45:570-576. [PubMed: 3928552] 
15. Sugimura, T.; Nagao, M.; Wakabayashi, K. Complex Factors Pertinent to Human Hazard and Risk. Wiley; New York: 2000. p. 349-359.

16. Adamson RH, Thorgeirsson UP, Snyderwine EG, Thorgeirsson SS, Reeves J, Dalgard DW, Takayama S, Sugimura T. Jpn. J. Cancer Res 1990;50:10-14. [PubMed: 1691162]

17. Anderson KE, Hammons GJ, Kadlubar FF, Potter JD, Kaderlik KR, Ilett KF, Minchin RF, Teitel CH, Chou HC, Martin MV, Guengerich FP, Barone GW, Lang NP, Peterson LA. Carcinogenesis 1997;18:1085-1092. [PubMed: 9163700]

18. Lang NP, Butler MA, Massengill J, Lawson M, Stotts RC, Hauer-Jensen M, Kadlubar FF. Cancer Epidemiol. Biomarkers Prev 1994;3:675-682. [PubMed: 7881341]

19. Shirai T, Sano M, Tamano S, Takahashi S, Hirose M, Futakuchi M, Hasegawa R, Imaida K, Matsumoto K, Wakabayashi K, Sugimura T, Ito N. Cancer Res 1997;57:195-198. [PubMed: 9000552]

20. Snyderwine EG. Cancer 1994;74:1070-1077. [PubMed: 8039141]

21. Ronco A, De Stefani E, Mendilaharsu M, Deneo-Pellegrini H. Int. J. Cancer 1996;65:328-331. [PubMed: 8575853]

22. Josephy PD, Evans DH, Parikh A, Guengerich FP. Chem. Res. Toxicol 1998;11:70-74. [PubMed: 9477228]

23. Josephy PD, Gruz P, Nohmi T. Mutat. Res 1997;386:1-23. [PubMed: 9100853]

24. Oda Y, Yamazaki H, Watanabe M, Nohmi T, Shimada T. Mutat. Res 1995;334:145-156. [PubMed: 7885366]

25. Oda Y, Aryal P, Terashita T, Gillam EM, Guengerich FP, Shimada T. Mutat. Res 2001;492:81-90. [PubMed: 11377247]

26. Nagao, M. Food-Borne Carcinogens: Heterocyclic Amines. Nagao, M.; Sugimura, T., editors. Wiley; New York: 2000. p. 31-71.

27. Sugimura T, Sato S. Cancer Res 1983;43:2415s-2421s. [PubMed: 6682010]

28. Hecht SS. Environ. Mol. Mutagen 2002;39:119-126. [PubMed: 11921179]

29. Kosakarn P, Halliday JA, Glickman BW, Josephy PD. Carcinogenesis 1993;14:511-517. [PubMed: 8453728]

30. Watanabe M, Ohta T. Carcinogenesis 1993;14:1149-1153. [PubMed: 8508501]

31. Terada M, Nagao M, Nakayasu M, Sakamoto H, Nakasato F, Sugimura T. Environ. Health Perspect 1986;67:117-119. [PubMed: 3757946]

32. Thompson LH, Tucker JD, Stewart SA, Christensen ML, Salazar EP, Carrano AV, Felton JS. Mutagenesis 1987;2:483-487. [PubMed: 3328038]

33. Felton JS, Fultz E, Dolbeare FA, Knize MG. Food Chem. Toxicol 1994;32:897-903. [PubMed: 7959444]

34. Felton JS, Knize MG, Dolbeare FA, Wu RW. Environ. Health Perspect 1994;102:201-204. [PubMed: 7889848]

35. Schut HA, Snyderwine EG. Carcinogenesis 1999;20:353-368. [PubMed: 10190547]

36. Turesky RJ. Drug Metab. Rev 2002;34:625-650. [PubMed: 12214671]

37. Thompson LH, Carrano AV, Salazar E, Felton JS, Hatch FT. Mutat. Res 1983;117:243-257. [PubMed: 6343852]

38. Aeschbacher HU, Ruch E. Carcinogenesis 1989;10:429-433. [PubMed: 2924390]

39. Tohda H, Oikawa A, Kawachi T, Sugimura T. Mutat. Res 1980;77:65-69. [PubMed: 7360158]

40. Yamazoe Y, Shimada M, Kamataki T, Kato R. Cancer Res 1983;43:5768-5774. [PubMed: 6416669]

41. Shimada T, Hayes CL, Yamazaki H, Amin S, Hecht SS, Guengerich FP, Sutter TR. Cancer Res 1996;56:2979-2984. [PubMed: 8674051]

42. Boobis AR, Lynch AM, Murray S, de la Torre R, Solans A, Farre M, Segura J, Gooderham NJ, Davies DS. Cancer Res 1994;54:89-94. [PubMed: 8261468]

43. Hammons GJ, Milton D, Stepps K, Guengerich FP, Tukey RH, Kadlubar FF. Carcinogenesis 1997;18:851-854. [PubMed: 9111224]

44. Guengerich FP. Drug Metab. Rev 2002;34:607-623. [PubMed: 12214670] 
45. Hickman D, Pope J, Patil SD, Fakis G, Smelt V, Stanley LA, Payton M, Unadkat JD, Sim E. Gut 1998;42:402-409. [PubMed: 9577349]

46. Hein DW, Doll MA, Rustan TD, Gray K, Feng Y, Ferguson RJ, Grant DM. Carcinogenesis 1993;14:1633-1638. [PubMed: 8353847]

47. Minchin RF, Reeves PT, Teitel CH, McManus ME, Mojarrabi B, Ilett KF, Kadlubar FF. Biochem. Biophys. Res. Commun 1992;185:839-844. [PubMed: 1627140]

48. Le Marchand L, Hankin JH, Pierce LM, Sinha R, Nerurkar PV, Franke AA, Wilkens LR, Kolonel LN, Donlon T, Seifried A, Custer LJ, Lum-Jones A, Chang W. Mutat. Res 2002;506-507:205-214.

49. Ishibe N, Sinha R, Hein DW, Kulldorff M, Strickland P, Fretland AJ, Chow WH, Kadlubar FF, Lang NP, Rothman N. Pharmacogenetics 2002;12:145-150. [PubMed: 11875368]

50. Zhou Y, Chladek S, Romano LJ. J. Org. Chem 1994;59:556-563.

51. Snyderwine EG, Roller PP, Adamson RH, Sato S, Thorgeirsson SS. Carcinogenesis 1988;9:10611065. [PubMed: 3370750]

52. Nagaoka H, Wakabayashi K, Kim SB, Kim IS, Tanaka Y, Ochiai M, Tada A, Nukaya H, Sugimura T, Nagao M. Jpn. J. Cancer Res 1992;52:1025-1029. [PubMed: 1452454]

53. Turesky RJ, Rossi SC, Welti DH, Lay JO Jr. Kadlubar FF. Chem. Res. Toxicol 1992;5:479-490. [PubMed: 1391614]

54. Guengerich FP, Mundkowski RG, Voehler M, Kadlubar FF. Chem. Res. Toxicol 1999;12:906-916. [PubMed: 10525265]

55. Gorlewska-Roberts K, Green B, Fares M, Ambrosone CB, Kadlubar FF. Environ. Mol. Mutagen 2002;39:184-192. [PubMed: 11921188]

56. Takayama K, Yamashita K, Wakabayashi K, Sugimura T, Nagao M. Jpn. J. Cancer Res 1989;49:1145-1148. [PubMed: 2516840]

57. Gangl ET, Turesky RJ, Vouros P. Anal. Chem 2001;73:2397-2404. [PubMed: 11403278]

58. Soglia JR, Turesky RJ, Paehler A, Vouros P. Anal. Chem 2001;73:2819-2827. [PubMed: 11467522]

59. Brown K, Hingerty BE, Guenther EA, Krishnan VV, Broyde S, Turteltaub KW, Cosman M. Proc. Natl. Acad. Sci. U.S.A 2001;98:8507-8512. [PubMed: 11438709]

60. Moriya M. Proc. Natl. Acad. Sci. U.S.A 1993;90:1122-1126. [PubMed: 8430083]

61. Shibutani S, Fernandes A, Suzuki N, Zhou L, Johnson F, Grollman AP. J. Biol. Chem 1999;274:27433-27438. [PubMed: 10488075]

62. Wang Z, Rizzo CJ. Org. Lett 2001;3:565-568. [PubMed: 11178826]

63. Elmquist CE, Stover JS, Wang Z, Rizzo CJ. J. Am. Chem. Soc 2004;126:11189-11201. [PubMed: 15355100]

64. Wu X, Shapiro R, Broyde S. Chem. Res. Toxicol 1999;12:895-905. [PubMed: 10525264]

65. Borer, PN. Handbook of Biochemistry and Molecular Biology. CRC Press; Cleveland, OH: 1975.

66. Piotto M, Saudek V, Sklenar V. J. Biomol. NMR 1992;6:661-665. [PubMed: 1490109]

67. Piantini U, Sorensen OW, Ernst RR. J. Am. Chem. Soc 1982;104:6800-6801.

68. Rance M, Sorensen OW, Hodenhausen G, Wagner G, Ernst RR, Wuthrich K. Biochem. Biophys.

Res. Commun 1983;177:479-485. [PubMed: 6661238]

69. Griesinger G, Sorensen OW, Ernst RR. J. Am. Chem. Soc 1985;107:6394-6396.

70. Sklenar V, Bax A, Zon G. FEBS Lett 1986;208:94-98. [PubMed: 3770213]

71. Sklenar V, Miyashiro H, Zon G, MIles HT, Bax A. FEBS Lett 1986;208:94-98. [PubMed: 3770213]

72. Keepers JW, James TL. J. Magn. Reson 1984;57:404-426.

73. Borgias BA, James TL. J. Magn. Reson 1990;87:475-487.

74. Liu H, Tonelli M, James TL. J. Magn. Reson. B 1996;111:85-89. [PubMed: 8620288]

75. Salazar M, Fedoroff OY, Miller JM, Ribeiro NS, Reid BR. Biochemistry 1993;32:4207-4215.

[PubMed: 7682844]

76. Brunger, AT. X-Plor. Version 3.1. A System for X-ray Crystallography and NMR. Yale University Press; New Haven: 1992.

77. Nilsson L, Karplus M. J. Comput. Chem 1986;7:591-616.

78. Lu XJ, Olson WK. Nucleic Acids Res 2003;31:5108-5121. [PubMed: 12930962] 
79. Reid BR. Q. Rev. Biophys 1987;20:2-28.

80. Patel DJ, Shapiro L, Hare D. Q. Rev. Biophys 1987;20:35-112. [PubMed: 2448843]

81. Boelens R, Scheek RM, Dijkstra K, Kaptein R. J. Magn. Reson 1985;62:378-386.

82. Fuchs RP, Schwartz N, Daune MP. Nature 1981;294:657-659. [PubMed: 7031481]

83. Norman D, Abuaf P, Hingerty BE, Live D, Grunberger D, Broyde S, Patel DJ. Biochemistry 1989;28:7462-7476. [PubMed: 2819081]

84. Gorenstein, DG. Phosphorus-31 chemical shifts and spin-spin coupling constant principles and empirical observations.. In: Gorenstein, DG., editor. Phosphorus-31 NMR Principles and Application. Academic Press; New York: 1984. p. 7-56.

85. Tjandra N, Tate S-I, Ono A, Kainosho M, Bax A. J. Am. Chem. Soc 2000;122:6190-6200.

86. Saenger, W. Principles of Nucleic Acid Structure. Springer; New York: 1984.

87. Solomon MS, Morgenthaler PM, Turesky RJ, Essigmann JM. J. Biol. Chem 1996;271:18368-18374. [PubMed: 8702479]

88. Burnouf D, Koehl P, Fuchs RPP. Proc. Natl. Acad. Sci. U.S.A 1989;86:4147-4151. [PubMed: 2657743]

89. Belguise-Valladier P, Fuchs RPP. Biochemistry 1991;30:10091-10100. [PubMed: 1931941]

90. Rodriguez H, Loechler EL. Carcinogenesis 1993;14:373-383. [PubMed: 8453713]

91. Rodriguez H, Loechler EL. Biochemistry 1993;32:1759-1769. [PubMed: 8439538]

92. Geacintov NE, Cosman M, Hingerty BE, Amin S, Broyde S, Patel DJ. Chem. Res. Toxicol 1997;10:111-146. [PubMed: 9049424]

93. Shukla R, Jelinsky S, Liu T, Geacintov NE, Loechler EL. Biochemistry 1997;36:13263-13269. [PubMed: 9341216]

94. Shukla R, Liu T, Geacintov NE, Loechler EL. Biochemistry 1997;36:10256-10261. [PubMed: 9254624]

95. Page JE, Zajc B, Oh-hara T, Lakshman MK, Sayer JM, Jerina DM, Dipple A. Biochemistry 1998;37:9127-9137. [PubMed: 9636059]

96. Fernandes A, Liu T, Amin S, Geacintov NE, Grollman AP, Moriya M. Biochemistry 1998;37:1016410172. [PubMed: 9665722]

97. Beland FA, Kadlubar FF. Environ. Health Perspect 1985;62:19-30. [PubMed: 4085422]

98. Fuchs RPP. J. Mol. Biol 1983;177:173-180. [PubMed: 6748082]

99. Bichara M, Fuchs RPP. J. Mol. Biol 1985;183:341-351. [PubMed: 3894674]

100. Melchior WB Jr. Marques MM, Beland FA. Carcinogenesis 1994;15:889-899. [PubMed: 8200092]

101. Tebbs RS, Romano LJ. Biochemistry 1994;33:8998-9006. [PubMed: 8043586]

102. O'Handley SF, Sanford DG, Xu R, Lester CC, Hingerty BE, Broyde S, Krugh TR. Biochemistry 1993;32:2481-2497. [PubMed: 8448107]

103. Mao B, Hingerty BE, Broyde S, Patel DJ. Biochemistry 1998;37:95-106. [PubMed: 9425029]

104. Mao B, Gorin A, Gu Z, Hingerty BE, Broyde S, Patel DJ. Biochemistry 1997;36:14479-14490. [PubMed: 9398167]

105. Broschard TH, Koffel-Schwartz N, Fuchs RP. J. Mol. Biol 1999;288:191-199. [PubMed: 10329136]

106. Burnouf DY, Miturski R, Fuchs RP. Chem. Res. Toxicol 1999;12:144-150. [PubMed: 10027791]

107. Koffel-Schwartz N, Fuchs RP. J. Mol. Biol 1995;252:507-513. [PubMed: 7563069]

108. Tan X, Suzuki N, Grollman AP, Shibutani S. Biochemistry 2002;41:14255-14262. [PubMed: 12450390]

109. Lambert IB, Napolitano RL, Fuchs RPP. Proc. Natl. Acad. Sci. U.S.A 1992;89:1310-1314. [PubMed: 1741385]

110. Garcia A, Lambert IB, Fuchs RP. Proc. Natl. Acad. Sci. U.S.A 1993;90:5989-5993. [PubMed: 8327472]

111. Milhe C, Dhalluin C, Fuchs RP, Lefevre JF. Nucleic Acids Res 1994;22:4646-4652. [PubMed: 7984413]

112. Milhe C, Fuchs RP, Lefevre JF. Eur. J. Biochem 1996;235:120-127. [PubMed: 8631318]

113. Ling H, Boudsocq F, Woodgate R, Yang W. Cell 2001;107:91-102. [PubMed: 11595188]

$J$ Am Chem Soc. Author manuscript; available in PMC 2009 June 8. 
114. Ling H, Boudsocq F, Woodgate R, Yang W. Mol. Cell 2004;13:751-762. [PubMed: 15023344]

115. Zang H, Goodenough AK, Choi JY, Irimia A, Loukachevitch LV, Kozekov ID, Angel KC, Rizzo CJ, Egli M, Guengerich FP. J. Biol. Chem 2005;280:29750-29764. [PubMed: 15965231]

116. Roy D, Hingerty BE, Shapiro R, Broyde S. Chem. Res. Toxicol 1998;11:1301-1311. [PubMed: 9815190]

117. Turesky RJ, Box RM, Markovic J, Gremaud E, Snyderwine EG. Mutat. Res 1997;376:235-241. [PubMed: 9202760] 
<smiles>Cn1c(N)nc2c3cccnc3ccc21</smiles><smiles>Cn1c(NO)nc2c3cccnc3ccc21</smiles><smiles>CC(=O)ONc1nc2c3cccnc3ccc2n1C</smiles><smiles>Cn1c([NH3+])nc2c3cccnc3ccc21</smiles>

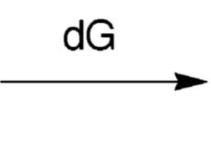
Aryl Nitrenium Ion<smiles>CCn1c(Nc2nc3c4cccnc4ccc3n2C)nc2c(=O)[nH]c(N)nc21</smiles>

\section{C8-dG IQ Adduct}

Chart 1.

Metabolic Activation of IQ 


$$
\begin{aligned}
& A \\
& 5^{\prime}-C^{1} T^{2} C^{3} G^{4} G^{5} C^{6} X^{7} C^{8} C^{9} A^{10} T^{11} C^{12}-3^{\prime} \\
& 3^{\prime}-G^{24} A^{23} G^{22} C^{21} C^{20} G^{19} C^{18} G^{17} G^{16} T^{15} A^{14} G^{13}-5^{\prime} \\
& X=C 8-d G \text { IQ adduct }
\end{aligned}
$$

B

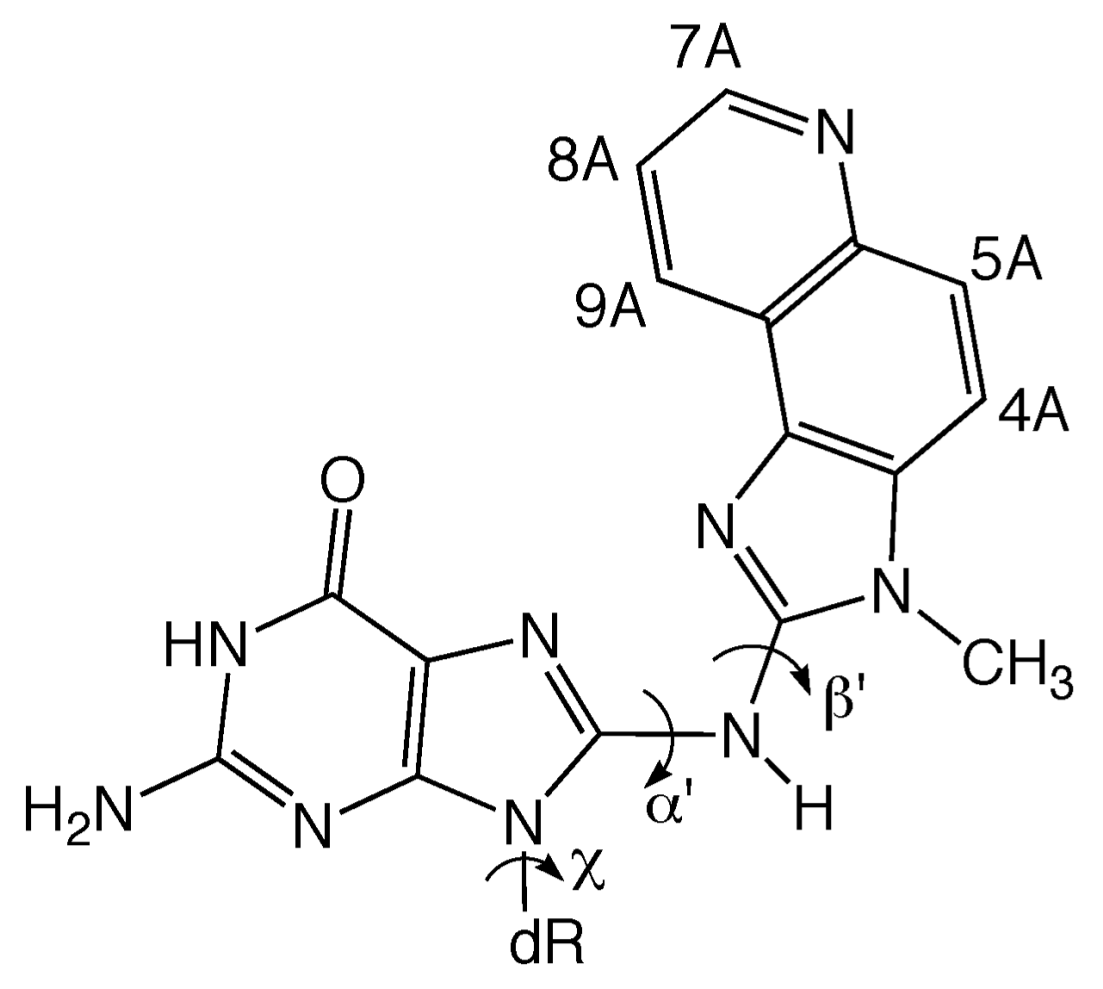

\begin{abstract}
a Torsion angles defining the IQ orientation in the duplex are $\chi$, the glycosyl torsion angle $\left(\mathrm{O}^{\prime}-\mathrm{C}^{\prime}-\mathrm{N} 9-\mathrm{C} 4\right), \alpha^{\prime}(\mathrm{N} 9-\mathrm{C} 8-\mathrm{N}[\mathrm{IQ}]-\mathrm{C} 2[\mathrm{IQ}])$, and $\beta^{\prime}(\mathrm{C} 8-\mathrm{N}[\mathrm{IQ}]-\mathrm{C} 2[\mathrm{IQ}]-\mathrm{N} 3[\mathrm{IQ}])$.
\end{abstract}

Chart 2.

(A) Nar1IQ3 Duplex and (B) C8-dG IQ Adduct ${ }^{\mathrm{a}}$ 

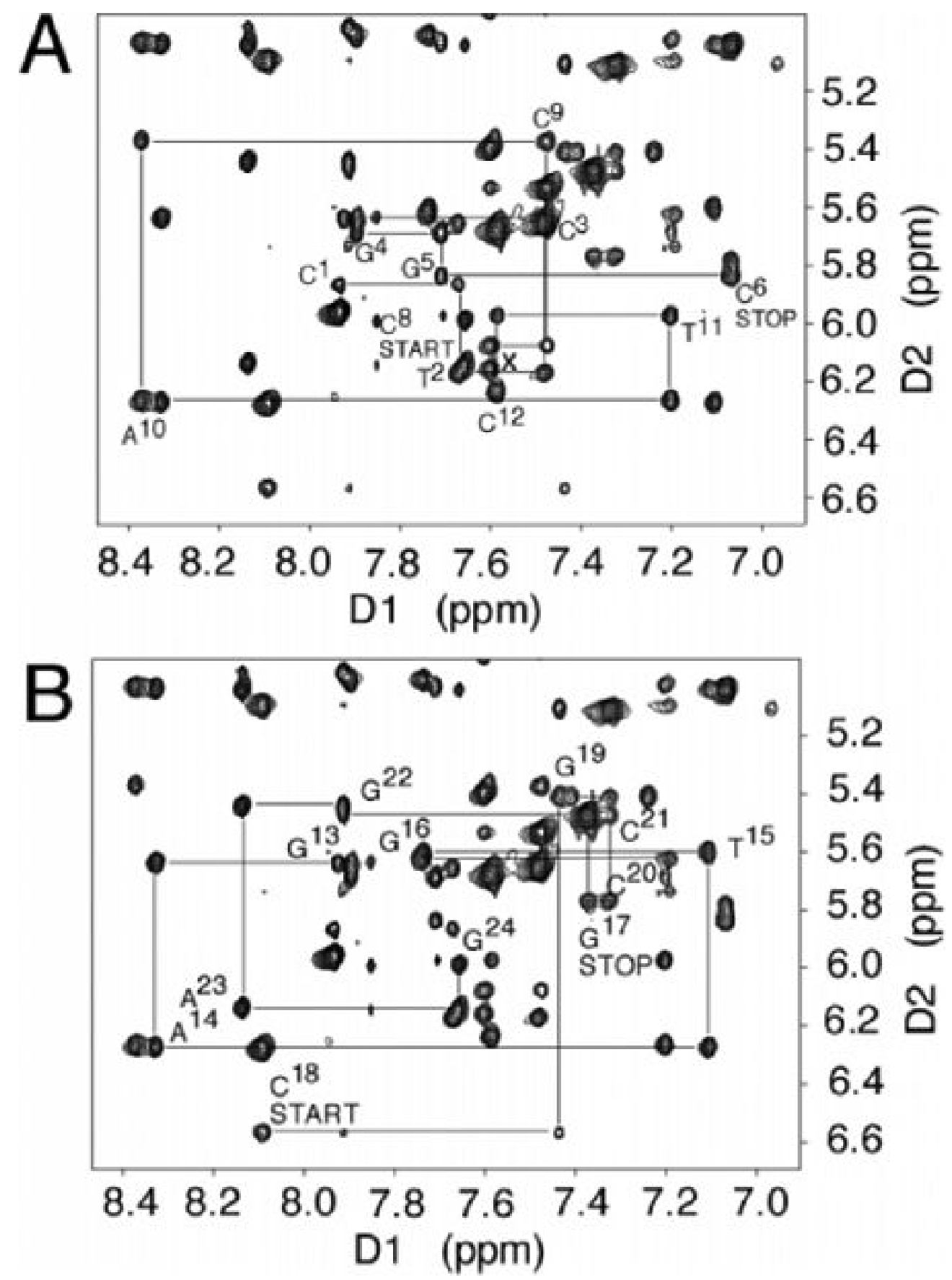

Figure 1.

Aromatic-anomeric proton region of the 800.13 MHz NOESY spectrum for the Nar1IQ3 duplex at $15^{\circ} \mathrm{C}$ at $250 \mathrm{~ms}$ mixing time, showing sequential NOE connectivity. (A) Nucleotides $\mathrm{C}^{1} \rightarrow \mathrm{C}^{12}$ of the modified strand. (B) Nucleotides $\mathrm{G}^{13} \rightarrow \mathrm{G}^{24}$ of the complementary strand. 


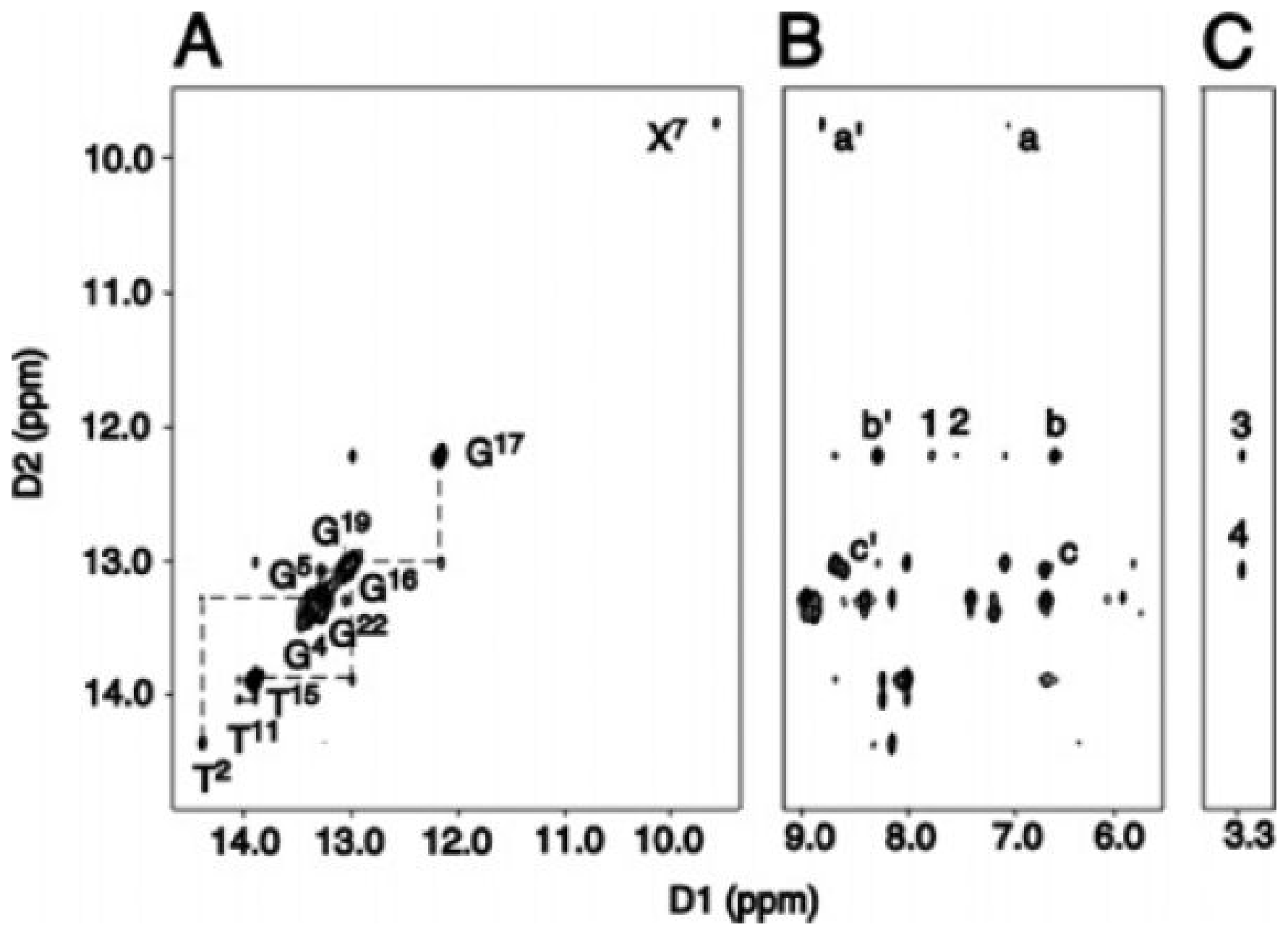

Figure 2.

(A) Sequential NOE connectivity for the imino protons of base pairs $\mathrm{T}^{2} \cdot \mathrm{A}^{23} \rightarrow \mathrm{T}^{11} \cdot \mathrm{A}^{14}$ for the Nar1IQ3 duplex at $5{ }^{\circ} \mathrm{C}$. The labels represent the imino proton of the designated base. (B) NOE connectivity between the imino protons and the base and amino protons. The cross-peaks involving the imino protons are labeled as: $\mathrm{a}^{\prime}, \mathrm{a}, \mathrm{X}^{7} \mathrm{~N} 1 \mathrm{H} \rightarrow \mathrm{X}^{7} \mathrm{NH}_{2}-2 \mathrm{~b}, \mathrm{e} ; \mathrm{b}^{\prime}, \mathrm{b}, \mathrm{G}^{17} \mathrm{~N} 1 \mathrm{H} \rightarrow$ $\mathrm{C}^{8} \mathrm{NH}_{2}-4 \mathrm{~b}, \mathrm{e} ; \mathrm{c}^{\prime}$ and $\mathrm{c}, \mathrm{G}^{19} \mathrm{~N} 1 \mathrm{H} \rightarrow \mathrm{C}^{6} \mathrm{NH}_{2}-4 \mathrm{~b}, \mathrm{e} ; 1, \mathrm{G}^{17} \mathrm{~N} 1 \mathrm{H} \rightarrow \mathrm{X}^{7} \mathrm{H} 4 \mathrm{~A} ; 2, \mathrm{G}^{17} \mathrm{~N} 1 \mathrm{H} \rightarrow$ $\mathrm{X}^{7} \mathrm{H} 5 \mathrm{~A}$. (C) NOE connectivity between the imino and the IQ methyl protons. The IQ-DNA cross-peaks labeled are as: $3, \mathrm{G}^{17} \mathrm{~N} 1 \mathrm{H} \rightarrow \mathrm{X}^{7} \mathrm{CH}_{3}$; and $4, \mathrm{G}^{19} \mathrm{~N} 1 \mathrm{H} \rightarrow \mathrm{X}^{7} \mathrm{CH}_{3}$. 

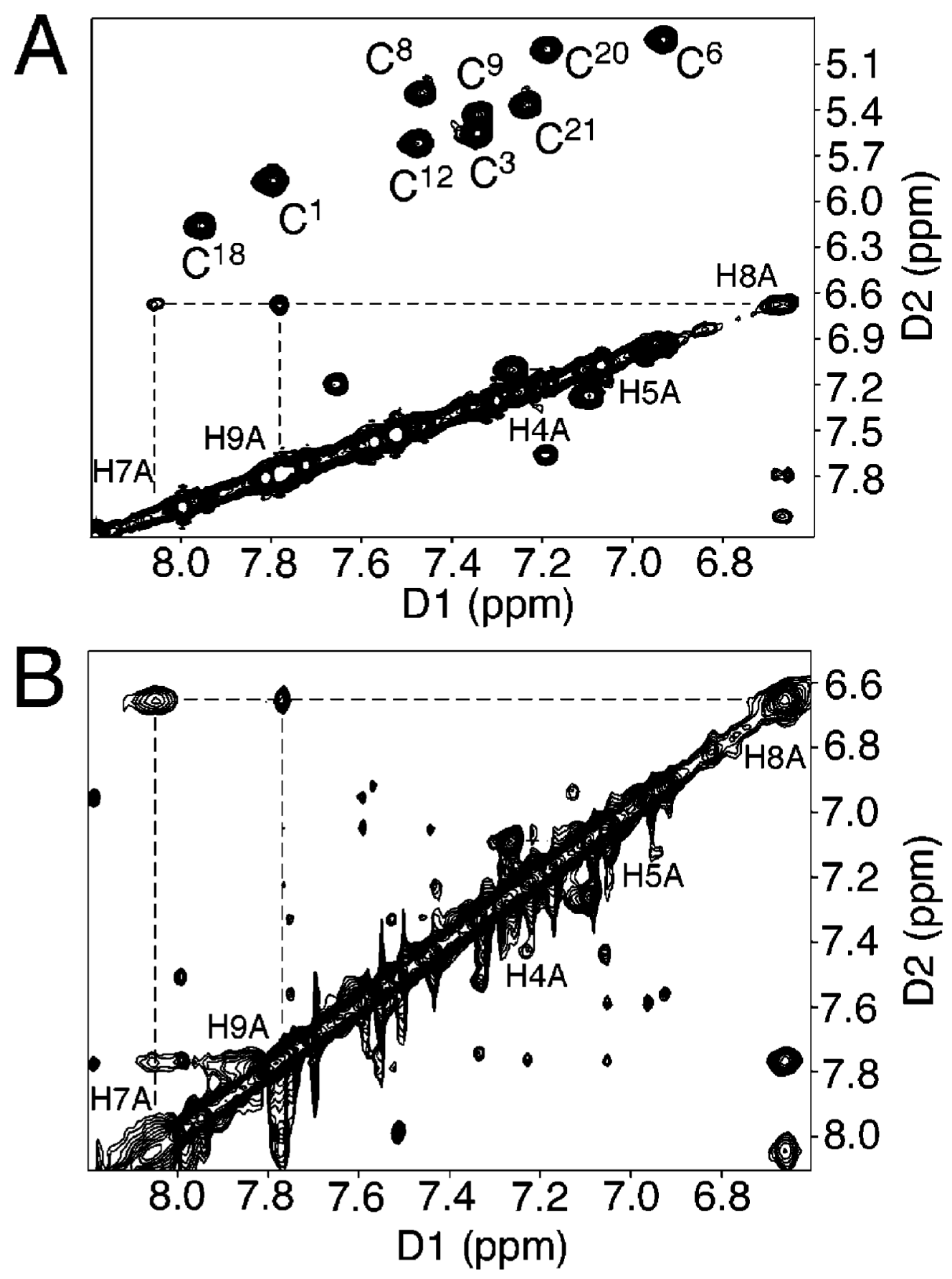

Figure 3.

Expanded plots from the COSY spectrum at $30^{\circ} \mathrm{C}$ and aromatic-aromatic region of the NOESY spectrum at $15{ }^{\circ} \mathrm{C}$ for the Nar1IQ3 duplex, showing assignments for the IQ protons. 


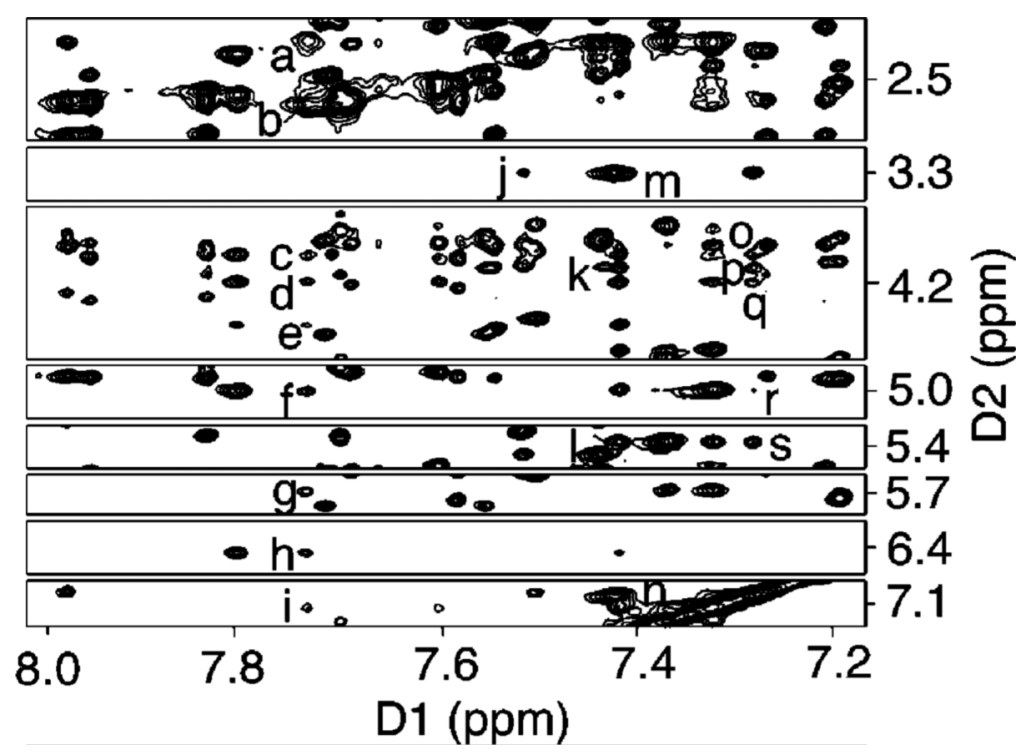

Figure 4.

NOE cross-peaks between nonexchangeable protons of DNA and IQ protons in the Nar1IQ3 duplex. (a-i) $\mathrm{G}^{17} \mathrm{H} 2^{\prime}, \mathrm{G}^{17} \mathrm{H} 2^{\prime \prime}, \mathrm{C}^{18} \mathrm{H}^{\prime}, \mathrm{H} 4^{\prime}, \mathrm{H}^{\prime \prime}, \mathrm{H} 3^{\prime}, \mathrm{G}^{17} \mathrm{H}^{\prime}, \mathrm{C}^{18} \mathrm{H}^{\prime}$, and $\mathrm{G}^{17} \mathrm{H} 8 \rightarrow \mathrm{IQ}$ $\mathrm{H} 9 \mathrm{~A} ;(\mathrm{j}) \mathrm{C}^{8} \mathrm{H6} \rightarrow \mathrm{IQ} \mathrm{CH}_{3}$; (k-l) $\mathrm{G}^{19} \mathrm{H}^{\prime}$ and $\mathrm{G}^{19} \mathrm{H}^{\prime} \rightarrow \mathrm{IQ} \mathrm{H} 4 \mathrm{~A} ;(\mathrm{m}-\mathrm{n}) \mathrm{G}^{19} \mathrm{H} 8 \rightarrow \mathrm{IQ}$ $\mathrm{CH}_{3}$ and $\mathrm{H} 5 \mathrm{~A} ;(\mathrm{o}-\mathrm{s}) \mathrm{G}^{19} \mathrm{H}^{\prime \prime}, \mathrm{G}^{19} \mathrm{H}^{\prime}, \mathrm{C}^{18} \mathrm{H}^{\prime}, \mathrm{C}^{18} \mathrm{H}^{\prime}$, and $\mathrm{G}^{19} \mathrm{H} 1^{\prime} \rightarrow$ IQ H5A, respectively. 

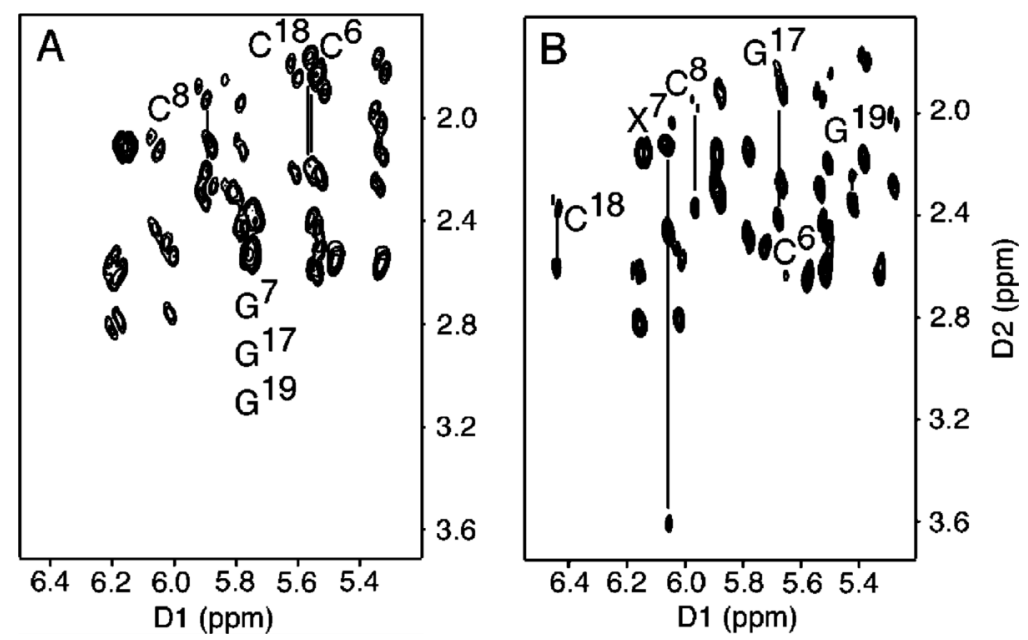

Figure 5.

Expanded COSY spectra at $15{ }^{\circ} \mathrm{C}$, establishing connectivity between the $\mathrm{H} 1^{\prime}$ and $\mathrm{H} 2^{\prime}, \mathrm{H} 2{ }^{\prime \prime}$ protons. The $\mathrm{H} 2^{\prime}$ and $\mathrm{H} 2^{\prime \prime}$ protons of the nucleotides adjacent to the lesion site are labeled. (A) Unmodified duplex. (B) Nar1IQ3 duplex. 


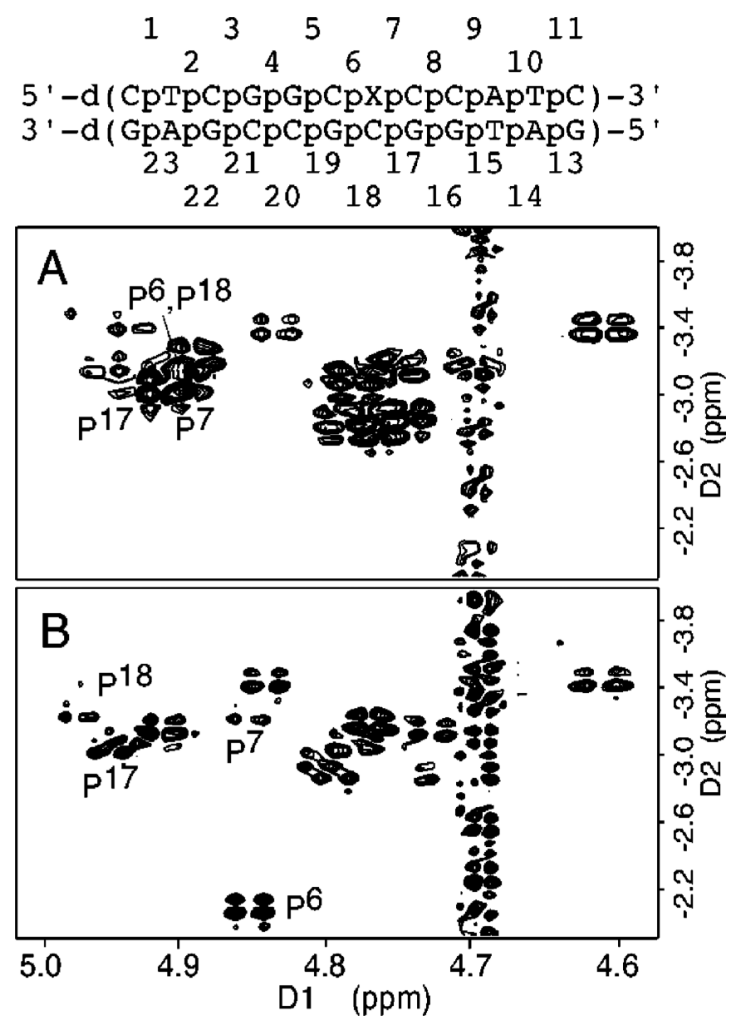

Figure 6.

$\mathrm{H} 3^{\prime}$ regions of nonselective excitation ${ }^{31} \mathrm{P}-{ }^{1} \mathrm{H}$ HMBC spectra of the unmodified (upper) and the Nar1IQ3 duplexes (lower). Both spectra were collected at $15^{\circ} \mathrm{C}$. 
$\begin{array}{llllllllllll}1 & 2 & 3 & 4 & 5 & 6 & 7 & 8 & 9 & 10 & 11 & 12\end{array}$

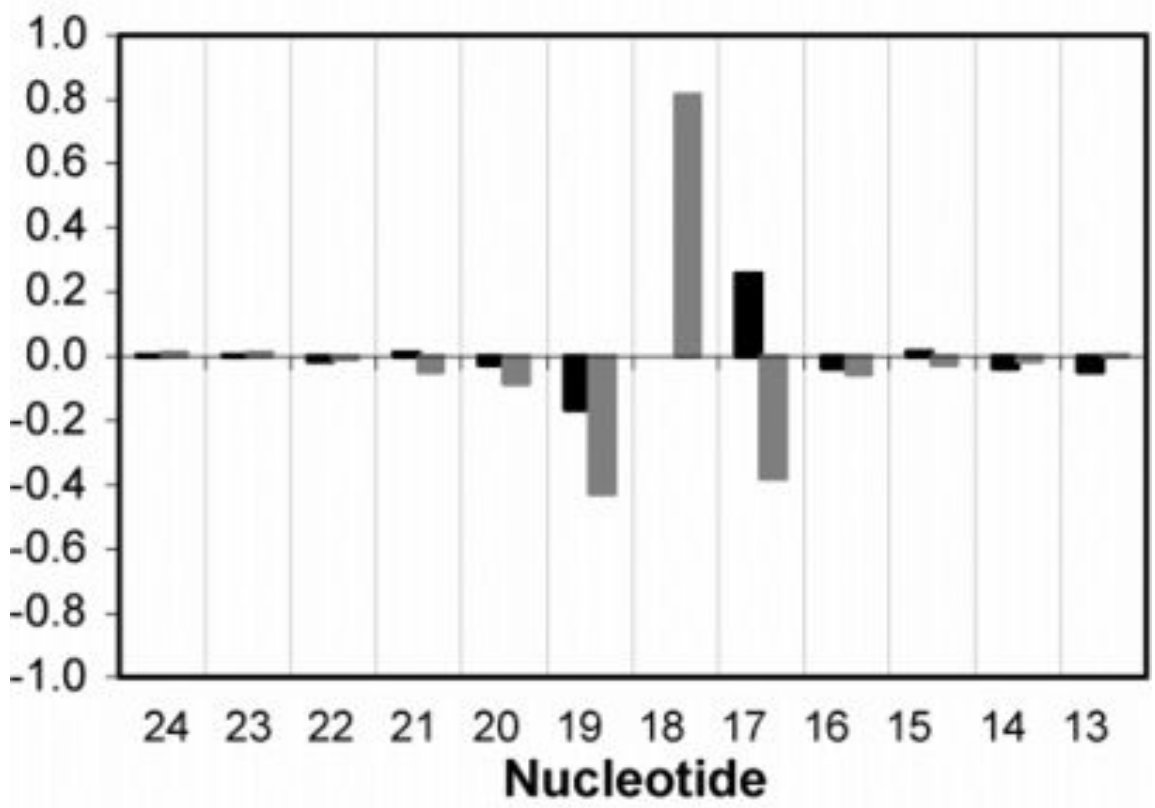

$\begin{array}{llllllllllll}1 & 2 & 3 & 4 & 5 & 6 & 7 & 8 & 9 & 10 & 11 & 12\end{array}$

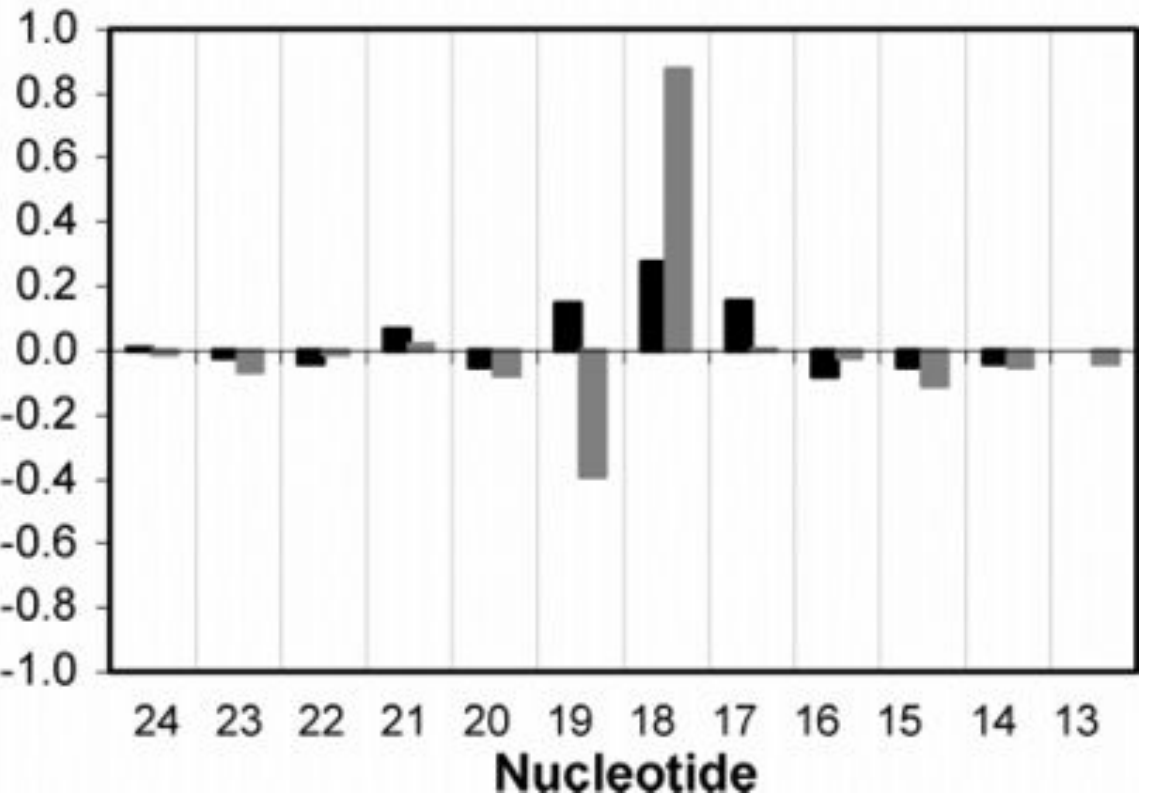

Figure 7.

Chemical shift perturbations of (top) H6/H8 and (bottom) H1' protons of the Nar1IQ3 duplex relative to the unmodified duplex. Dark bars represent the modified strand; light bars represent the complementary strand. $\Delta \delta=\left[\delta_{\text {modified oligodeoxynucleotide }}-\delta_{\text {unmodified oligodeoxynucleotide }}\right]$ (ppm). 

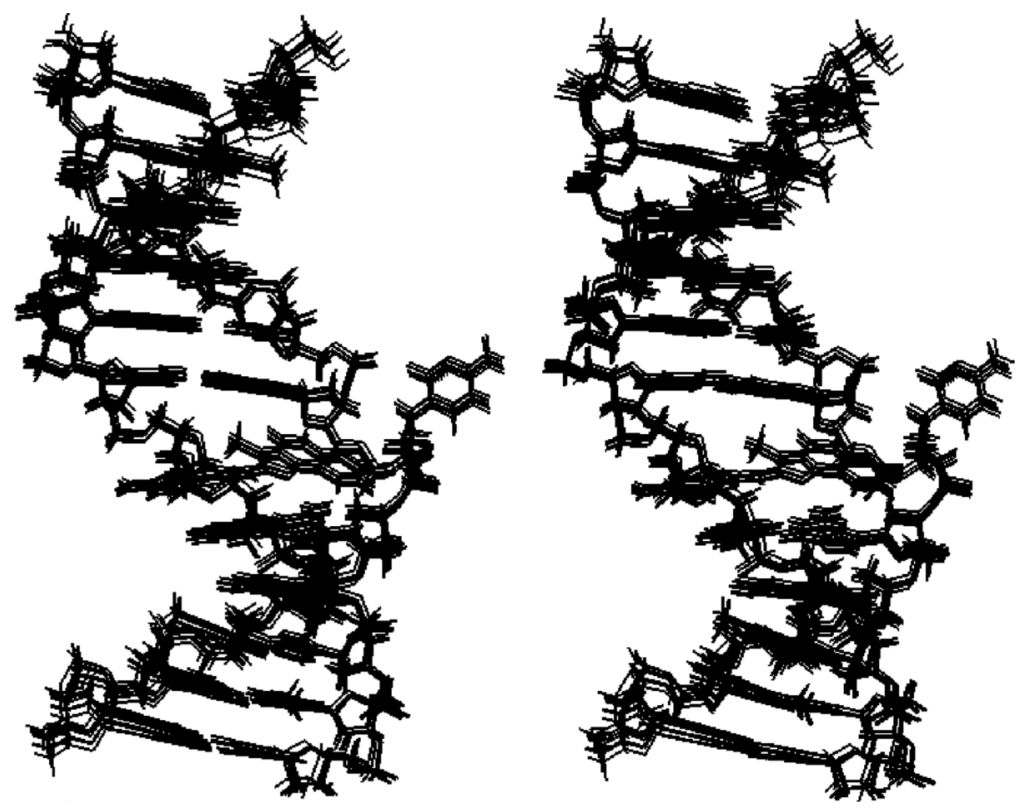

Figure 8.

Stereoview of 10 superimposed structures emergent from randomly seeded rMD calculations on the Nar1IQ3 duplex. 

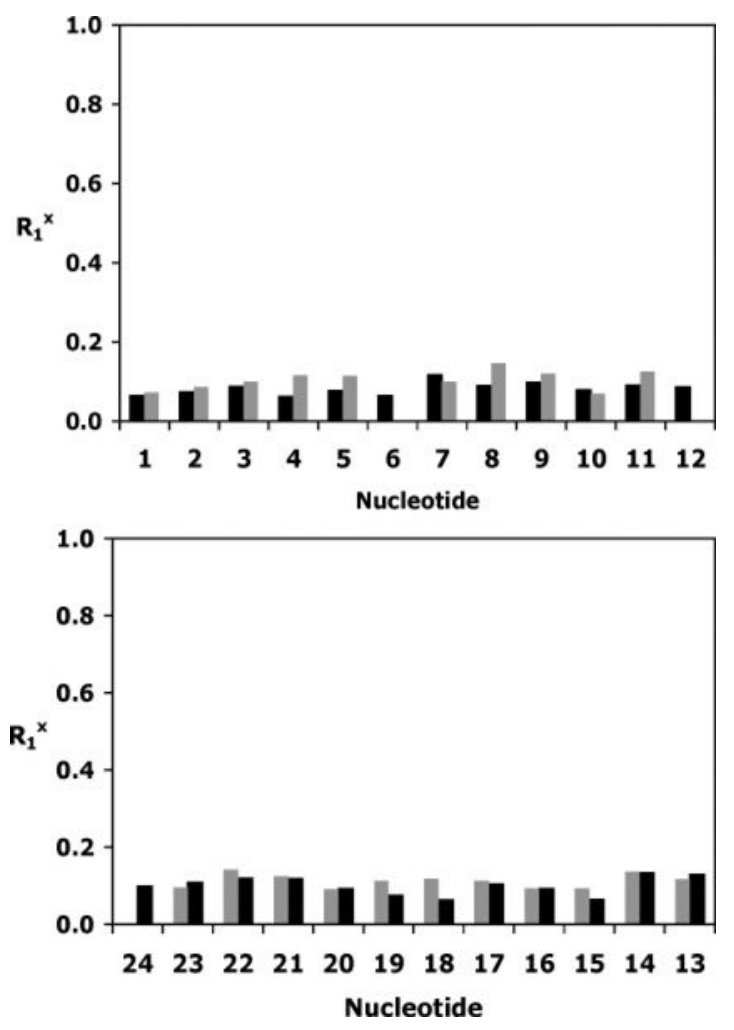

Figure 9.

Sixth root residuals for NOE intensities of the Nar1IQ3 duplex. (Top) Nucleotides $\mathrm{C}^{1} \rightarrow$ $\mathrm{C}^{12}$. (Bottom) Nucleotides $\mathrm{G}^{13} \rightarrow \mathrm{G}^{24}$. Dark bars represent intranucleotide values; light bars represent internucleotide values. 

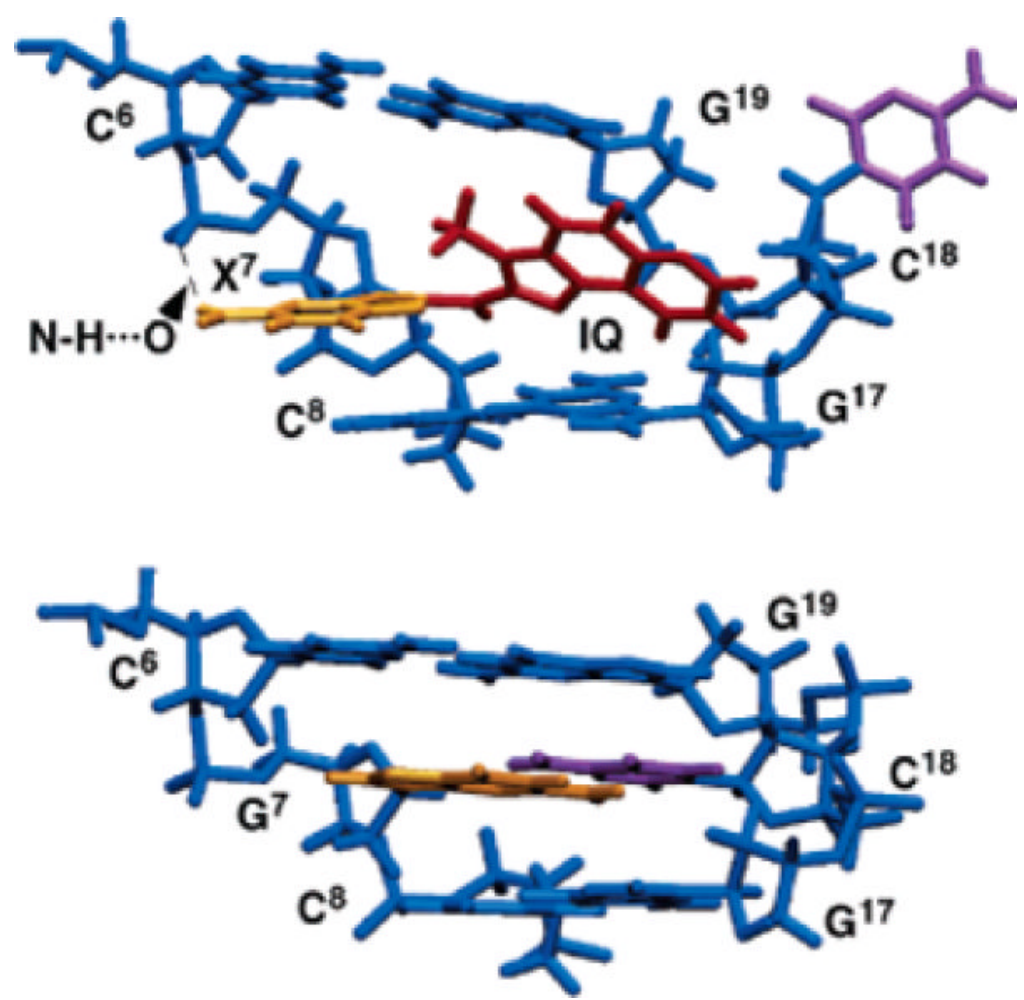

Figure 10.

Comparison of the average structures, looking into the major groove and normal to the helix axis of the central segment. (A) Nar1IQ3 duplex. The IQ ring is shown in red and is inserted between base pairs $C^{6} \cdot G^{19}$ and $C^{8} \cdot G^{17}$. (B) Unmodified duplex. 
A

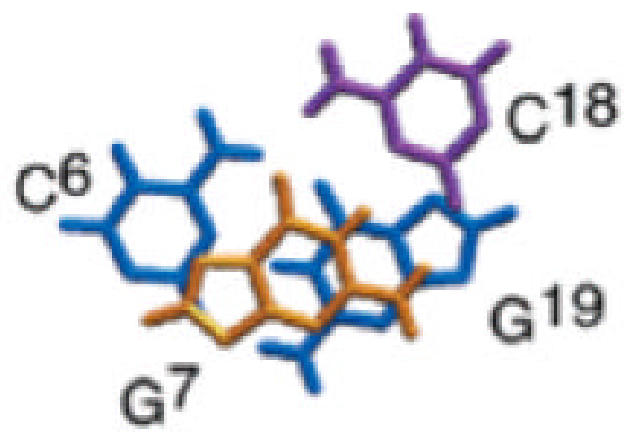

B
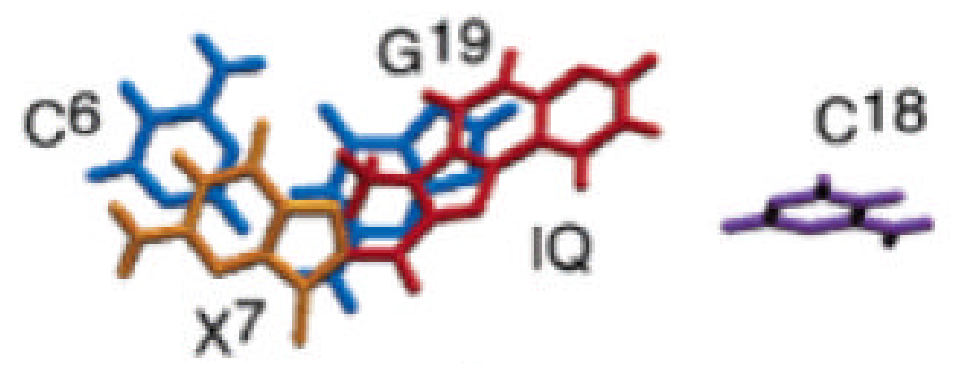

C

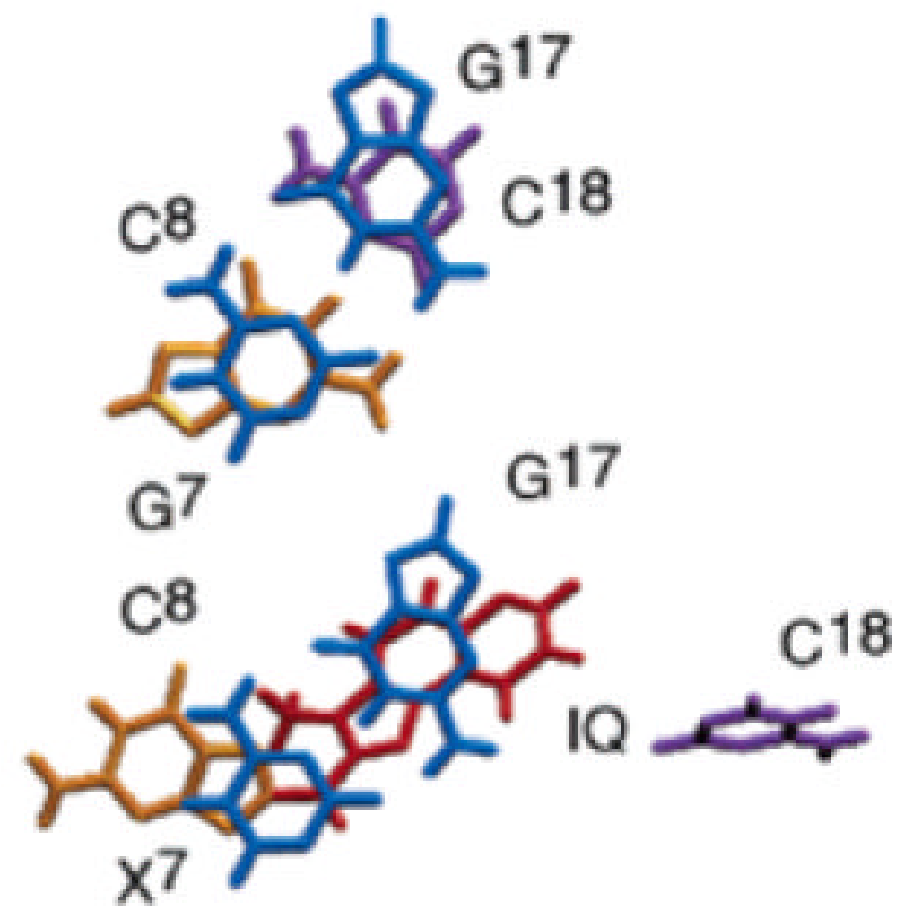

Figure 11.

Base stacking of the Nar1IQ3 and the unmodified duplexes. (A) Unmodified duplex. Stacking of $\mathrm{C}^{6} \cdot \mathrm{G}^{19}$ and $\mathrm{G}^{7} \cdot \mathrm{C}^{18}$. (B) Nar1IQ3 duplex. Stacking of $\mathrm{C}^{6} \cdot \mathrm{G}^{19}$ and $\mathrm{X}^{7} \cdot \mathrm{C}^{18}$. (C) Unmodified duplex. Stacking of $G^{7} \cdot C^{18}$ and $C^{8} \cdot G^{17}$. (D) Nar1IQ3 duplex. Stacking of $X^{7} \cdot C^{18}$ and $C^{8}$. $\mathrm{G}^{17}$. 
Table 1

Analysis of RMD-Generated Structures of the Unmodified and Nar1IQ3 Duplexes

\begin{tabular}{|c|c|c|}
\hline NMR restraints & NarI & Nar1IQ3 \\
\hline total no. of distance restraints & 463 & 488 \\
\hline interresidue distance restraints & 138 & 148 \\
\hline intraresidue distance restraints & 325 & 340 \\
\hline DNA-IQ distance restraints & 0 & 24 \\
\hline IQ-IQ distance restraints & 0 & 5 \\
\hline $\mathrm{H}$-bonding restraints & 33 & 30 \\
\hline dihedral planarity restraints & 24 & 22 \\
\hline sugar pucker restraints & 120 & 120 \\
\hline backbone torsion angle restraints & 90 & 78 \\
\hline \multicolumn{3}{|l|}{ structural statistics } \\
\hline NMR R-factor $\left(\mathrm{R}_{1}^{x}\right)\langle r M D R i\rangle$ & $0.0812 \pm 0.0003$ & $0.0854 \pm 0.0005$ \\
\hline rmsd of NOE violations $(\AA)$ & $0.00763 \pm 0.00001$ & $0.00798 \pm 0.00002$ \\
\hline $\begin{array}{l}\text { no. of NOE violations }>0.2 \AA \text { in the root-mean-square deviations } \\
\text { from ideal geometry }\end{array}$ & 0 & 0 \\
\hline bond length $(\AA)$ & $0.02402 \pm 0.00005$ & $0.02783 \pm 0.00006$ \\
\hline bond angle (deg) & $2.613 \pm 0.007$ & $2.672 \pm 0.006$ \\
\hline improper angle (deg) & $0.64 \pm 0.02$ & $0.79 \pm 0.02$ \\
\hline pairwise rmsd ( $\AA$ ) over all atoms $\langle r M D R i\rangle$ vs $\langle r M D a v\rangle$ & $0.65 \pm 0.01$ & $0.68 \pm 0.02$ \\
\hline
\end{tabular}

